\title{
Histologic Study of the Possible Protective Effect of Resveratrol Versus Resveratrol-Loaded Niosomes Against Titanium Dioxide Nanoparticles-Induced Toxicity on Adult Rat Seminiferous Tubules
}

\author{
Original \\ Amany A. Solaiman', Iman Nabil', Heba S. Ramadan ${ }^{2}$ and Amira Abulfotooh Eid ${ }^{3}$ \\ Article \\ ${ }^{1}$ Department of Histology and Cell Biology, Faculty of Medicine, Alexandria University, Egypt. \\ ${ }^{2}$ Department of Medical Biophysics, Medical Research Institute, Alexandria University, Egypt. \\ ${ }^{3}$ Department of Dermatology, Venereology and Andrology, Faculty of Medicine, \\ Alexandria University, Egypt.
}

\begin{abstract}
Background: Titanium dioxide nanoparticles $\left(\mathrm{TiO}_{2}-\mathrm{NPs}\right)$ are widely used in several fields and safety concerns about their potential reproductive hazards have been raised. Resveratrol (RES) was reported to protect against $\mathrm{TiO}_{2}-\mathrm{NPs}_{\text {-induced toxicity }}$ through its antioxidant and anti-inflammatory properties. However, owing to its low bioavailability, resveratrol-loaded nanoparticles (RES-loaded niosomes) have been developed and were found to have higher antioxidant and anti-inflammatory properties.

Aim: To investigate the possible protective effect of RES versus RES-loaded niosomes against $\mathrm{TiO}_{2}$ - NPs-induced toxicity on adult rat seminiferous tubules rats.

Materials and Methods: 60 adult male albino rats were divided into 6 equal groups that daily received distilled water, RES, RES-loaded niosomes, $\mathrm{TiO}_{2}-\mathrm{NPs}$, $\mathrm{TiO}_{2}-\mathrm{NPs}$ in addition to RES, and $\mathrm{TiO}_{2}-\mathrm{NPs}$ in addition to RES-loaded niosomes, respectively for 90 days. At the end of the experiment, rats were sacrificed; blood to measure testosterone, MDA and LDH and semen samples to evaluate sperm count were collected. Both testes were processed for light and electron microscopic examination.

Results: Administration of $\mathrm{TiO}_{2}$-NPs led to significantly lower testosterone level, sperm count and Johnsen score, significantly elevated MDA and LDH levels and degenerative changes in the seminiferous epithelium. Administration of RES with TiO -

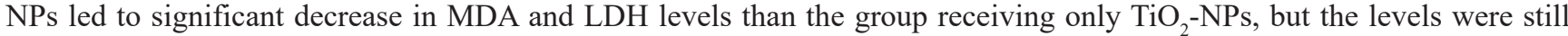
significantly higher than the first three groups. Administration of RES-loaded niosomes with $\mathrm{TiO}_{2}$-NPs led to significant increase in serum testosterone, sperm count and Johnsen score and significant reduction in MDA and LDH levels together with apparent structural improvement of the seminiferous tubules on light and electron microscopic examination compared to the groups receiving $\mathrm{TiO}_{2}$-NPs and RES with $\mathrm{TiO}_{2}$-NPs.

Conclusion: RES-loaded niosomes possibly exerts a protective effect against $\mathrm{TiO}_{2}$-NPs-induced testicular damage and hence might play a role against nanoparticle-induced reproductive toxicity.
\end{abstract}

Received: 01 February 2020, Accepted: 11 March 2020

Key Words: Reproductive toxicity, resveratrol, resveratrol loaded niosomes, seminiferous tubules, titanium dioxide nano particles.

Corresponding Author: Iman Nabil, MD, Department of Histology and Cell Biology, Faculty of Medicine, Alexandria University, Almoasah-Alhadara, Alexandria, Egypt, Tel.: +20 1004149637 , E-mail: emannabil4@gmail.com

ISSN: 1110-0559, Vol. 43, No.4

\section{INTRODUCTION}

Nanomaterials, unlike bulk material of the same composition, are unique in their physicochemical properties; they are of an ultra small size, have a large surface area to mass ratio and are highly reactive. These unique properties make them suitable candidates for use in several fields ${ }^{[1]}$. Owing to their photocatalytic, optical and dielectric properties $^{[2]}$, titanium dioxide nanoparticles $\left(\mathrm{TiO}_{2}-\mathrm{NPs}\right)$ are nowadays the most widely used in a wide array of medical and non-medical applications ${ }^{[3-5]}$.
$\mathrm{TiO}_{2}$ occurs in three forms: anatase, rutile and brookite Rutile is the most stable in the bulk form, whereas in the nanoparticle form the anatase is the most stable of the three forms ${ }^{[2]}$. Due to the $\mathrm{TiO}_{2}$-NPs small size, they can enter the body through several routes and hence may have a negative impact on various organs and accordingly on human health ${ }^{[6]}$.

Concerns about genotoxic and cytotoxic potential of TiO2-NPs exist. They have been found to cause DNA strand breaks and chromosomal damage. The DNA damaging effect of NPs could be attributed to excessive production of 
reactive oxygen species, defective antioxidant mechanisms and impaired synthesis of DNA repair proteins ${ }^{[7]}$.

Both male and female reproductive systems can be affected by $\mathrm{TiO}_{2}$-NPs. Histopathological changes in both testes and ovaries induced by exposure to $\mathrm{TiO}_{2}$-NPs were previously reported ${ }^{[8,9]}$. Compared to other organs, the testis was found to be highly sensitive to the toxic effects of $\mathrm{TiO}_{2}-\mathrm{NPs}^{[10,11]}$. Furthermore, $\mathrm{TiO}_{2}-\mathrm{NPs}$ can be transferred during pregnancy to the male offspring and aggregate in the spermatids, Sertoli cells and Leydig cells, leading to dose-dependent changes in testicular histology ultimately producing detrimental effects on spermatogenesis ${ }^{[12]}$.

Resveratrol (3,5,4'-trihydroxystilbene) is a natural phytoalexin found in different dietary sources such as peanuts, grapes, plums and berries. Its trans form is well known to have anti-inflammatory, antioxidant, anti-tumor, anti-aging as well as bone protective effects ${ }^{[13,14]}$. In fact, it was found to be a more potent antioxidant than vitamins $\mathrm{C}$ and $\mathrm{E}^{[15]}$. The beneficial effect of resveratrol (RES) includes several body organs and systems ${ }^{[16]}$. It was reported to reduce oxidative stress and inflammation following exposure to $\mathrm{TiO}_{2}-\mathrm{NPS}^{[17,18]}$. Hence, RES might exhibit a protective effect against $\mathrm{TiO}_{2}$-NPs- induced toxicity.

Despite the wide range of therapeutic effects of RES, its biopharmaceutical properties limit its bioavailability and accordingly its use ${ }^{[14,19]}$. To surpass these obstacles, nanotechnology based drug delivery systems are being developed to enhance bioavailability to improve its health benefits ${ }^{[20]}$. RES-loaded nanocarriers were shown to have higher concentrations with higher safety, higher antioxidant and anti-inflammatory properties compared to free RES ${ }^{[21,22]}$. Niosomes are non ionic surfactant vesicles that have been extensively studied as nanoscale drug delivery systems, which have the ability of loading lipophylic and hydrophilic drugs. They have the advantage of being capable of overcoming problems related to drug stability, solubility and bioavailability ${ }^{[23,24]}$

The present work aimed to investigate the possible protective effect of RES versus RES-loaded niosomes against $\mathrm{TiO}_{2}$-NPs-induced toxicity on the seminiferous tubules of the adult albino rats.

\section{MATERIALS AND METHODS}

\section{Chemicals}

Anatase $\mathrm{TiO}_{2}-\mathrm{NPs}$ (purity $>99.5 \%$ ), Trans-resvertrol (purity $>98 \%$ ), sorbitan monooleate (Span 60) and cholesterol $95 \%$ were purchased from Sigma Aldrich (St. Louis, MO, USA).

\section{Preparation of $\mathrm{TiO}_{2}-\mathrm{NPs}$}

$\mathrm{TiO}_{2}$-NPs $(50 \mu \mathrm{g} / \mathrm{mL})$ were dispersed in distilled water. The suspending solution was ultrasonicated (VWR ${ }^{\circledR}$, Malaysia) at $4.2 \times 105 \mathrm{~kJ} / \mathrm{m} 3$ for $15-20$ minutes and mechanically vibrated for five minutes ${ }^{[25]}$. $\mathrm{TiO}_{2}$-NPs were given by intra-gastric administration in a daily dose of 10 $\mathrm{mg} / \mathrm{kg}$, which is equivalent to an exposure dose of $0.15-0.7 \mathrm{~g}$ $\mathrm{TiO}_{2}-\mathrm{NPs}$ in a $60-70 \mathrm{~kg}$ body weight human ${ }^{[9]}$.

\section{Preparation of RES}

The RES suspension for oral dosing was prepared by suspending $10 \mathrm{mg} / \mathrm{kg}$ RES in one $\mathrm{mL}$ distilled water. The suspension was shaken vigorously before oral administration $^{[26]}$.

\section{Preparation of RES-loaded niosomes}

RES-loaded niosomes were prepared by adding Span 60 and cholesterol in the molar ratios of 7:6 to $50 \mathrm{mg}$ of RES; they were then dissolved in a $10 \mathrm{~mL}$ mixture of chloroform and ethanol in a round bottom flask of a rotator evaporator. Extraction of the organic phase was done by evaporation at $55 \mathrm{oC}$ under pressure of $200 \mathrm{mmHg}$ until a thin film on the inner wall of the flask was obtained. This was followed by hydration of the dry lipid film with phosphate buffer saline (PBS) (pH 7.4) and shaking at 55oC at low speed. The mixture was hand shaken for 15 minutes at room temperature to obtain a lipid suspension. A bath-type sonicator operating at $55 \mathrm{KHz}$ for $5-10$ minutes was utilized to down size the particles $^{[27]}$.

Determination of unloaded RES in the supernatant was done using UV-Vis spectrophotometer at $\lambda \max 305 \mathrm{~nm}$ (PG Instruments Ltd., United Kingdom). The encapsulation efficiency of RES-loaded niosomes was calculated according to the following equation: $\mathrm{EE}=[(\mathrm{Dt}-\mathrm{Du}) / \mathrm{Dt}] \mathrm{x} 100(\mathrm{Dt}$ is the total amount of drug and $\mathrm{Du}$ is the amount of free drug $)^{[28]}$.

\section{Solubility studies}

To measure the saturated solubility, $10 \mathrm{mg}$ of RES were added to $10 \mathrm{~mL}$ of distilled water, the mixture was shaken for 48 hours at $37 \mathrm{oC}$ and the solution was then centrifuged at high speed for 10 minutes. The Supernatant was collected and analyzed using a UV-Vis spectrophotometer at $305 \mathrm{~nm}$. The same procedure was used to measure the solubility of RES in RES-loaded niosomes ${ }^{[29]}$.

\section{Characterization of $\mathrm{TiO}_{2}-\mathrm{NPS}$ and RES-loaded niosomes}

\section{1- Transmission electron microscopy (TEM)}

TEM (Jeol 1400 plus, Tokyo, Japan) was used for determining the size of NPs. A small drop of each of $\mathrm{TiO}_{2}-$ NPs and RES-loaded niosomes was placed onto TEM grids, coated with carbon film and allowed to evaporate. Digital pictures of several locations on the grid were taken ${ }^{[25,30]}$.

\section{2-Zeta potential measurement}

Samples of $\mathrm{TiO}_{2}$-NPs and RES-loaded niosomes were diluted in distilled water. The zeta potential was measured using a Nano Zetasizer particle analyzer (nanoseries, Malvern, UK) using the soft ware provided by the manufacturer ${ }^{[21]}$.

\section{Animal treatment}

The study was carried on 60 adult male albino rats weighing $200 \mathrm{~g}-210 \mathrm{~g}$. The animals were housed under standard conditions, with free access to water and standard food pellets and in a controlled 12/12hr light/dark cycle. 
Room temperature was kept at $22 \pm 2^{\circ} \mathrm{C}$. All procedures were approved by the local medical ethics committee and conform with the criteria of animal care in the "Guide for the Care and Use of Laboratory Animals". The rats were allowed to acclimatize for one week prior to the experiment. Rats were divided into 6 equal age- and weight-matched groups each containing ten rats as follows:

Group I (control group): received $1 \mathrm{mg} / \mathrm{kg}$ distilled water.

Group II: received RES in a dose of $10 \mathrm{mg} / \mathrm{kg}$. The oral dose of RES was determined based on the minimal effective dose in similar studies in animals and on the recommended dose for RES supplementation in humans ${ }^{[31]}$.

Group III: received RES-loaded niosomes in a dose of $10 \mathrm{mg} / \mathrm{kg}$.

Group IV: received $10 \mathrm{mg} / \mathrm{kg} \mathrm{TiO}_{2}-\mathrm{NPs}$.

Group V: received $\mathrm{TiO}_{2}-\mathrm{NPs}$ in a dose similar to that of group IV and RES in a dose similar to group II.

Group VI: received $\mathrm{TiO}_{2}$-NPs in a dose similar to that of group IV and RES-loaded niosomes similar to group III.

All treatments were given orally daily for 90 days $^{[32]}$.

Twenty-four hours after the last treatment, rats were sacrificed under deep anesthesia with ether, blood samples were collected from the retro-orbital venous plexus of all rats for hormonal and biochemical studies. Blood samples were allowed to clot, they were then centrifuged at $1000 \mathrm{~g}$ for 15 minutes, serum was separated and stored at $-20 \mathrm{oC}$. The epididymides were removed and processed for evaluating sperm count and the right and left testes were excised and processed for light and electron microscopic examination respectively.

\section{Hormonal Assay}

On the time of the assay, sera and reagents were brought down to room temperature, and serum testosterone was measured using enzyme-linked immunosorbent assay (ELISA) kit (Abbott, Vienna, Austria.) following the specified manufacturer's instructions. Measured testosterone was expressed in $\mathrm{ng} / \mathrm{mL}$.

\section{Biochemical study}

\section{Serum malondialdehyde (MDA)}

As a marker of oxidative stress, serum MDA was measured using the MDA colorimetric assay by a Humalyzer junior photometer (Human diagnostics, Wiesbaden, Germany). MDA in the samples reacts with thiobarbituric acid (TBA) to generate MDA-TBA adduct that can easily be quantified colorimetrically; the absorbance was determined at $532 \mathrm{~nm}^{[33]}$.

\section{Serum lactate dehydrogenase ( $\mathrm{LDH})$}

LDH is an oxidoreductase, and its activity increases in association with oxidative stress ${ }^{[34]}$. Total LDH activity was measured using LDH (EC 1.1.1.27) colorimetric assay (abcam, MA, USA) according to the manufacturer's instructions. Absorbance was measured at $450 \mathrm{~nm}$.

\section{Light microscopic study}

The right testes were fixed in Bouin's solution for 24 hours followed by fixation in $10 \%$ formol saline. After processing, $5-\mu \mathrm{m}$ thick paraffin sections were prepared and stained with hematoxylin and eosin stains. The seminiferous tubules were evaluated using the Johnsen score for rats, in which all tubules in one section were examined and given a score from one to 10 according to the degree of germ cell maturity. The mean score was then calculated by dividing the sum of scores by the number of the tubules examined ${ }^{[35]}$.

\section{Electron microscopic study}

The left testis of each rat was cut into small pieces (about $1 \times 1 \mathrm{~mm} 3$ ), fixed in 3\% phosphate-buffered gluteraldehyde at $\mathrm{pH}$ 7.4. They were then postfixed in $1 \%$ osmium tetra oxide in phosphate buffer. Ultra thin sections were prepared and stained with uranyl acetate and lead citrate ${ }^{[36]}$. Sections were examined with TEM (Jeol 1400 plus, Tokyo, Japan).

\section{Epididymal sperm count}

The left cauda epididymis of each rat was minced thoroughly in $1 \mathrm{~mL}$ phosphate buffered saline (PBS, pH 7.2). The resultant suspension was filtered through a mesh and then $0.05 \mathrm{~mL}$ from the filtrate was diluted with PBS 1:40 and introduced to the Neubauer counting chamber. To determine the total sperm count per epididymis, the number of sperms in eight squares ( $1 \mathrm{~mm} 2$ each) was counted and multiplied by $5 \times 104^{[37]}$.

\section{Statistical analysis}

Data (including serum testosterone, serum MDH and LDH, sperm count, percentage of motile sperms, testicular weight and Johnsen score) were expressed as the mean $\pm \mathrm{SD}$, and analyzed using statistical package for the social sciences (SPSS, version 20; IBM SPSS, Armonk, NY, USA). Statistical analysis was carried out using one-way analysis of variance (ANOVA) and the post-hoc test (Tukey) for pair wise comparison. The level of significance was set at $P$ value $\leq 0.05$.

\section{RESULTS}

The study was conducted on age- and weight-matched adult male albino rats divided in six equal groups. On comparing testicular weight of the rats in the studied groups, no significant difference was detected $(p=0.939)$ (Table 1$)$.

\section{NPs characteristics}

$\mathrm{TiO}_{2}$-NPs and RES-loaded niosomes by TEM had a size range of 36- $41 \mathrm{~nm}$ and 74- $96 \mathrm{~nm}$ respectively (Figures 1a, b). The zeta potential of $\mathrm{TiO}_{2}$-NPs was -37.3 $\mathrm{mV}$ and-33.9 $\mathrm{mV}$ for RES-loaded niosomes, thus they were considered stable. The saturation solubility of RES-loaded niosomes was eight folds that of RES (Figure 1c).

No significant difference was detected between the control group and the group receiving RES regarding all studied parameters (Table 1). 


\section{Hormonal assay}

Significantly lower serum testosterone levels were detected in the group receiving $\mathrm{TiO}_{2}$ (group IV) compared to all other groups, and in the group receiving $\mathrm{TiO}_{2}$ and $\mathrm{RES}$ (group V) compared to groups I, II, III and VI. Significantly higher serum testosterone levels were detected in group III compared to groups IV and V. In group VI, serum testosterone was significantly higher than in groups IV and V $(p<0.001)$ (Table 1).

\section{Biochemical study}

\section{$M D A$}

Significantly higher serum MDA levels were detected in group IV compared to other studied groups. In group VI, MDA levels were significantly lower than in groups IV and V. Levels in group V were significantly higher than in groups I, II, III and VI and significantly lower than in group $\operatorname{IV}(p<0.001)$ (Table 1).

\section{LDH}

Serum LDH levels were significantly higher in group IV compared to all studied groups and in group V compared to groups I, II, III and VI. Group VI, showed significantly lower LDH levels compared to groups IV and V $(p<0.001)$ (Table 1).

\section{Epididymal sperm count}

Epididymal sperm count was significantly higher in group VI compared to groups I, II, IV and V. It was also significantly higher in group III compared to groups I, II, IV and $\mathrm{V}$. The count in groups IV and $\mathrm{V}$ were significantly lower than count in the remaining groups $(p<0.001)$ (Table1).

\section{Johnsen score}

Johnsen scoring was significantly lower in the groups receiving $\mathrm{TiO}_{2} \mathrm{NPs}$ and $\mathrm{TiO}_{2} \mathrm{NPs}$ and RES (groups IV and V respectively) compared to groups I, II, III and VI $(p<0.001)$. No significant difference was detected among groups I,II, III and VI regarding Johnsen scores. (Table1).

\section{Histopathologic Changes}

\section{Group I (control group)}

The control rat testis showed multiple closely packed seminiferous tubules with narrow interstitial spaces in between. These tubules were lined by Sertoli cells and spermatogenic cells. Sertoli cells exhibited large \& pale nuclei. Spermatogonia were characterized by their basal location and depicted oval to rounded nuclei. Primary spermatocytes were identified by their large and rounded nuclei that showed various patterns of chromatin condensation. At the adluminal compartment of the tubules, early and late spermatids lied. The early spermatids revealed pale nuclei. A flat peritubular myoid cells were seen, surrounding the basal lamina. (Figure 2a).

\section{Group II (RES) and Group III (RES-loaded niosomes)}

The rat testis of these two groups showed closely packed seminiferous tubules lined by normal Sertoli cells and spermatogenic cells that simulated the control group (Figures $2 \mathrm{~b}, \mathrm{c}$ ) respectively.

\section{Group IV (TiO $-\mathrm{NPS})$}

The rat seminiferous tubules that received $\mathrm{TiO}_{2} \mathrm{NPs}$ revealed numerous changes in the form of vacuolation of the seminiferous epithelium, irregularity of its basal lamina, focal loss of spermatogenic cells, degenerating germ cells with small dark nuclei and hypereosinophilic cytoplasm as well as multinucleated giant cells inside the tubular lumen containing nuclei of spermatids.(Figures 3a-d).

\section{Group $\mathrm{V}\left(\mathrm{TiO}_{2}-\mathrm{NPS}\right.$ and $\left.\mathrm{RES}\right)$}

The seminiferous tubules of this group showed some degenerative changes manifested by vacuolation and degenerating germ cells (Figures 4a,b).

\section{Group VI (TiO - NPs and RES-loaded niosomes)}

The seminiferous tubules of this group showed apparently normal Sertoli cell as well as spermatogenic cells (Figure 4C).

\section{Ultrastructural changes}

\section{Group I (control group)}

Ultrastructural examination of control rat seminiferous tubules revealed Sertoli cells with large, euchromatic nuclei and prominent nucleolus. Type A spermatogonium with its oval nucleus and type B spermatogonium with its rounded nucleus were both encountered. Primary spermatocytes depicted large rounded nuclei. An intact blood testis barrier was also noticed (Figures 5a-d). Early spermatids were identified by their pale nuclei with acrosomal vesicle and multiple peripherally situated mitochondria. Multiple spermatozoa were frequently encountered in the lumen of the tubules with their characteristic tails (Figures 5e-f).

\section{Group II (RES) and Group III (RES-loaded niosomes)}

Electron microscopic examination of these groups respectively revealed normally appearing seminiferous tubules, Sertoli cells and spermatogenic cells (Figures 6,7).

\section{Group IV ( $\mathrm{TiO}_{2}$-NPs)}

Electron microscopic examination of the seminiferous tubules showed areas of rarified cytoplasm, and swollen mitochondria with disrupted cristae in the cytoplasm of Sertoli cells. The spermatogenic cells revealed small and electron dense nuclei, dilated perinuclear cisternae and defective nuclei with focal loss and disintegration of chromatin. Spermatozoa exhibited defective tails; middle pieces showed mitochondria with disrupted cristae and principal pieces appeared with focal interruption of the circumferential ribs. Focal dilatation of the blood testis barrier was noticed (Figures 8a-h). 


\section{Group V: (TiO $-\mathrm{NPS}$ and $\mathrm{RES})$}

The rats of this group still exhibited marked changes in the seminiferous tubules that showed pronounced vacuolation in the cytoplasm of Sertoli cells, defective nuclei and dilatation of perinuclear cistarnae of the primary spermatocytes. Late spermatids showed malformed head and swollen mitochondria with disrupted cristae. Middle
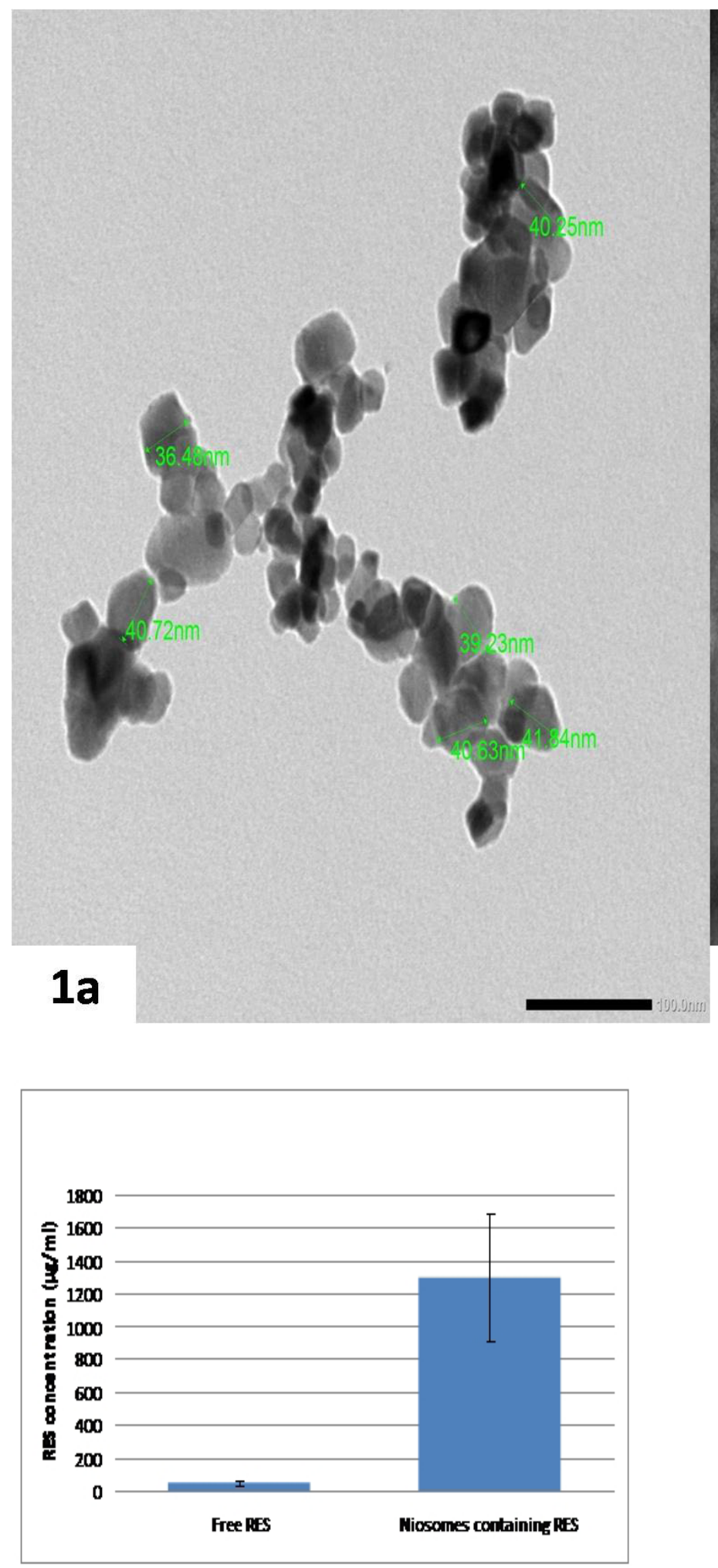

pieces of the sperm tails showed swollen and disorganized mitochondria (Figures 9a-c).

\section{Group VI ( $\mathrm{TiO}_{2}$-NPs and RES-loaded niosomes)}

The seminiferous tubules depicted apparent structural improvement except for mild vacuolation in the cytoplasm of the Sertoli cell (Figures 10a-c).

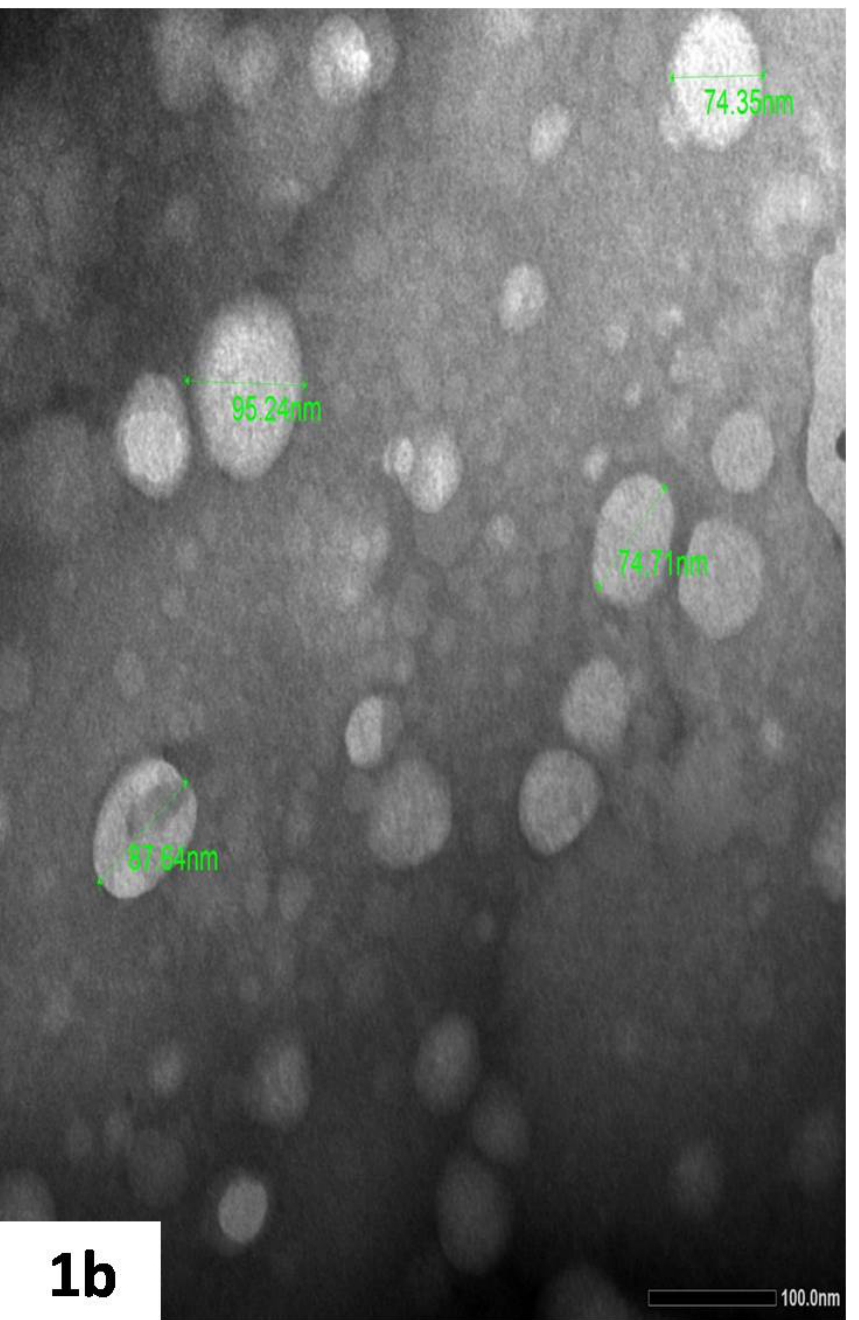

Fig. 1a-c: 1a\&b;TEM micrographs demonstrating: (a)- TiO2-NPs (diameter ranging from 36.48 to $41.84 \mathrm{~nm}$ ) and (b)-RES loaded niosomes (diameter ranging from 74.35 to95.24 nm), (c)- a bar chart showing the saturation solubility of RES-loaded niosomes versus free RES. 

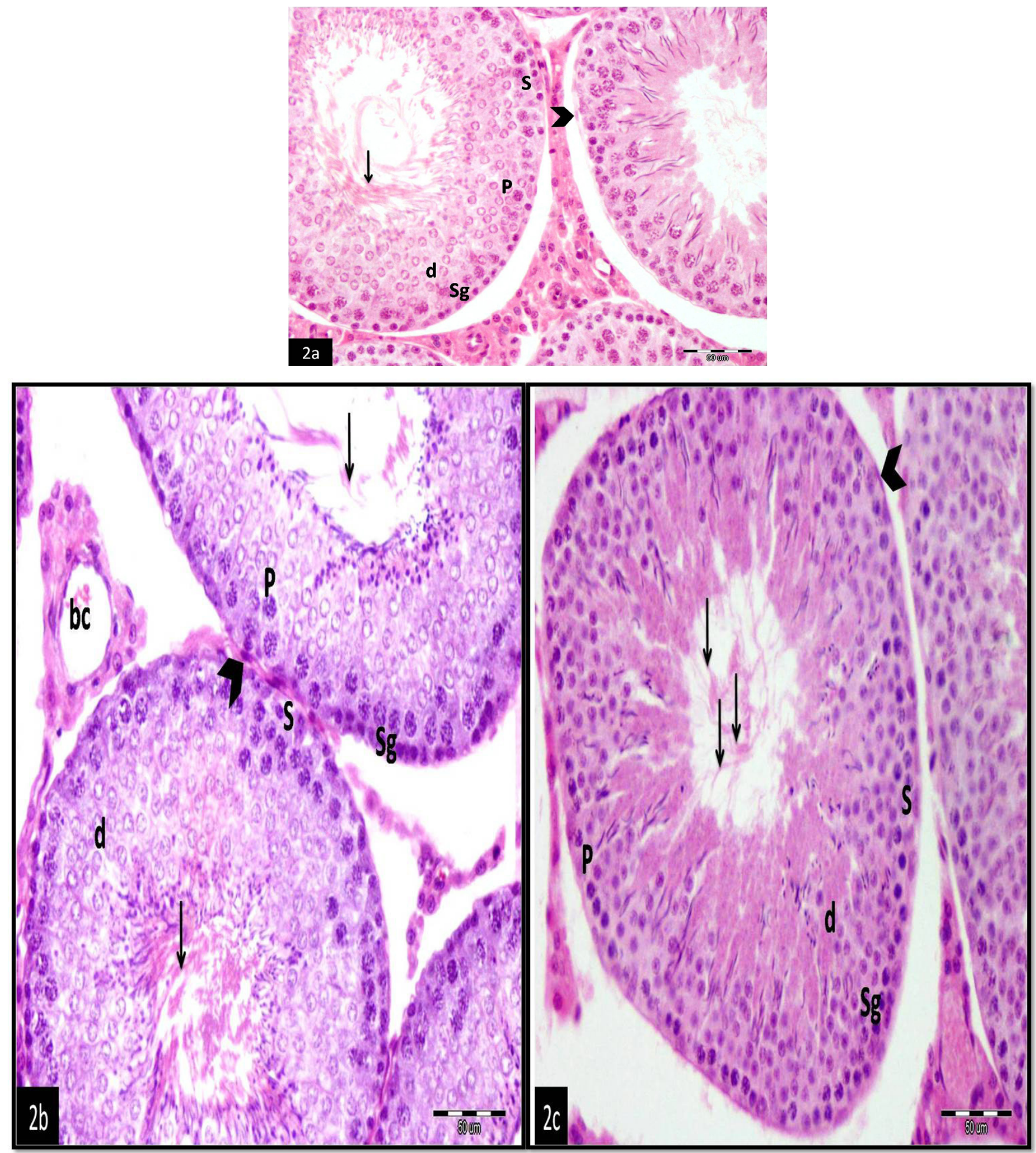

Fig. 2a-c:Photomicrographs of rat testis; (a)- group I (control group), (b)- group II that received RES and (c)- group III received RES-loaded niosomes showing closely packed seminiferous tubules lined by: Sertoli cell (S) Spermatogonia (Sg), primary spermatocytes (P), early spermatids (d) and numerous spermatozoa $(\uparrow) .\left({ }^{\wedge}\right)$; myoid cells. bc; blood capillary in B. H\&E stain, Mic. Mag. $x 400$ 

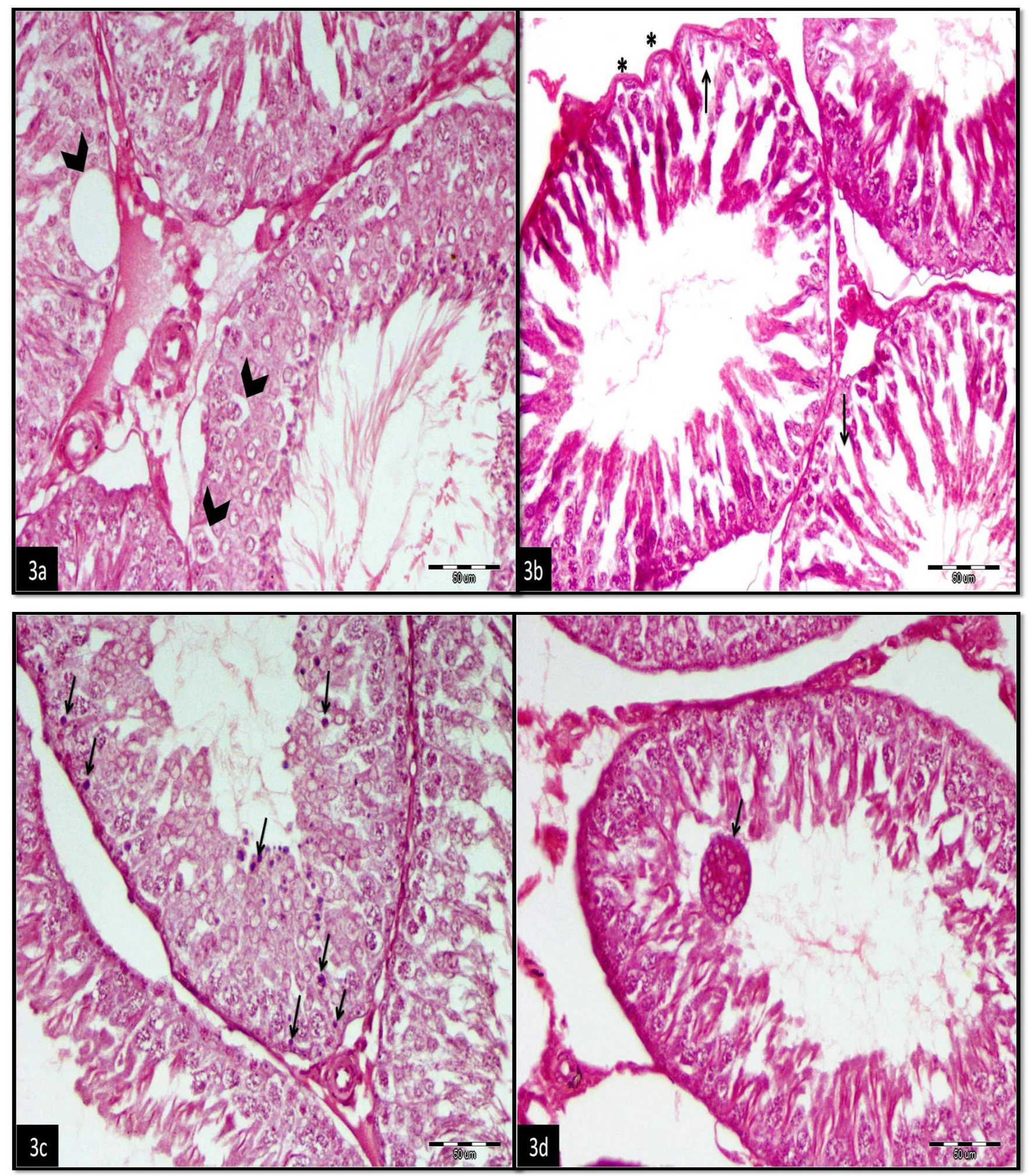

Fig. 3a-d: Photomicrographs of rat testis (group IV) that received TiO2-NPs showing: (a)- Vacuolation of the seminiferous epithelium $\left({ }^{\wedge}\right)(b)-$ Irregular and scalloped basal lamina (*)with focal loss of spermatogenic cells $(\uparrow)$ (c)- Degenerating germ cells $(\uparrow)$ with small dark nucleus and eosinophilic cytoplasm (d)Multinucleated giant cell within the tubular lumen containing nuclei of spermatids $(\uparrow)$. H\&E stain, Mic. Mag. $x 400$. 

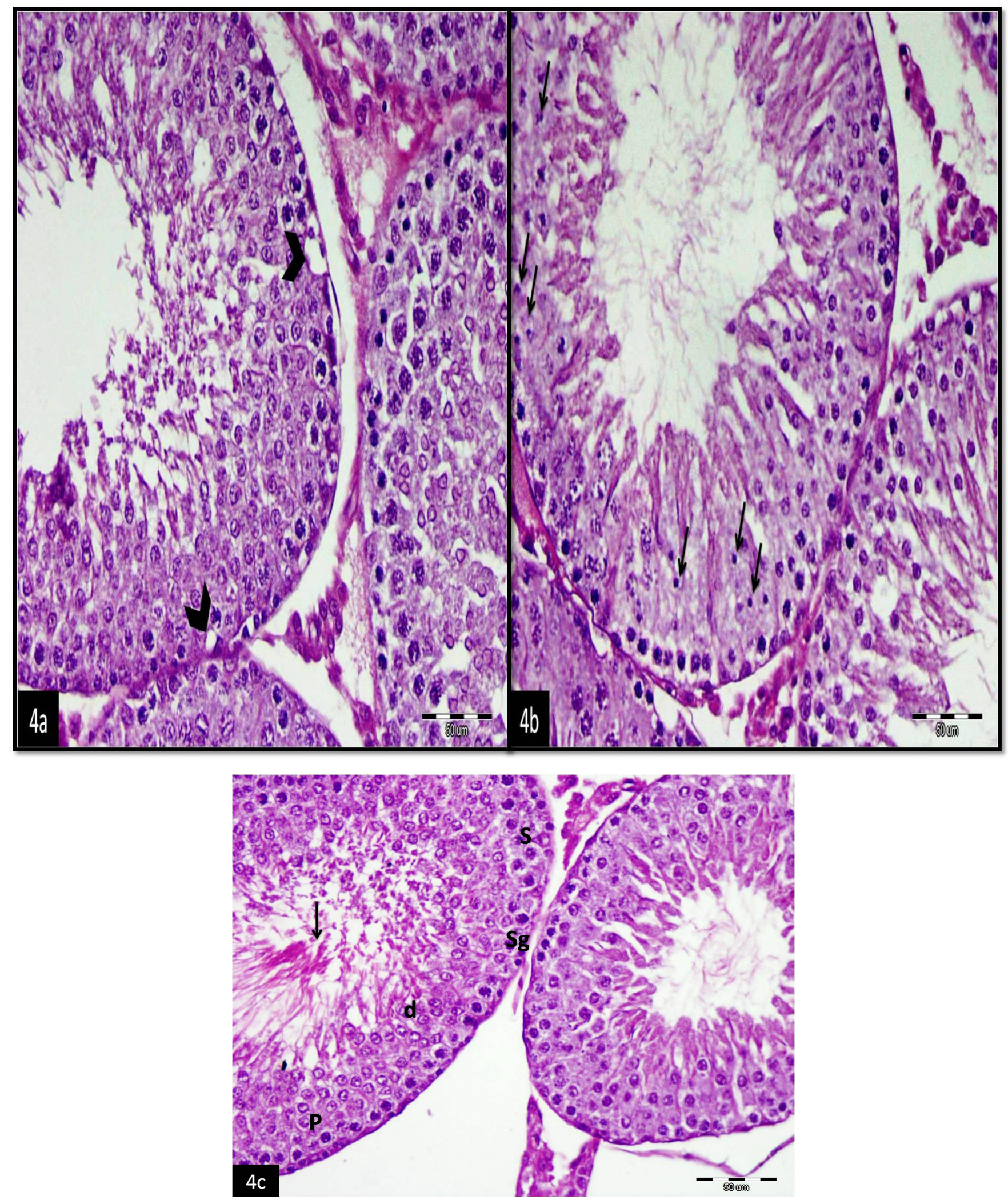

Fig. 4a-c:Photomicrographs of rat seminiferous tubules: a,b ; Group V that received TiO2-NPs and RES showing: (a)- Vacuolation within the tubular epithelium $\left(^{\wedge}\right)$. (b)- Degenerating spermatogenic cells $(\uparrow)$. (c)- Group VI that received TiO2-NPs and RES-loaded niosomes showing apparently normal Sertoli cell(S), spermatogonium (Sg), primary spermatocyte (P), early spermatid (d), muliple spermatozoa in the lumen ( $\uparrow)$. H\&E stain, Mic. Mag. $x 400$. 

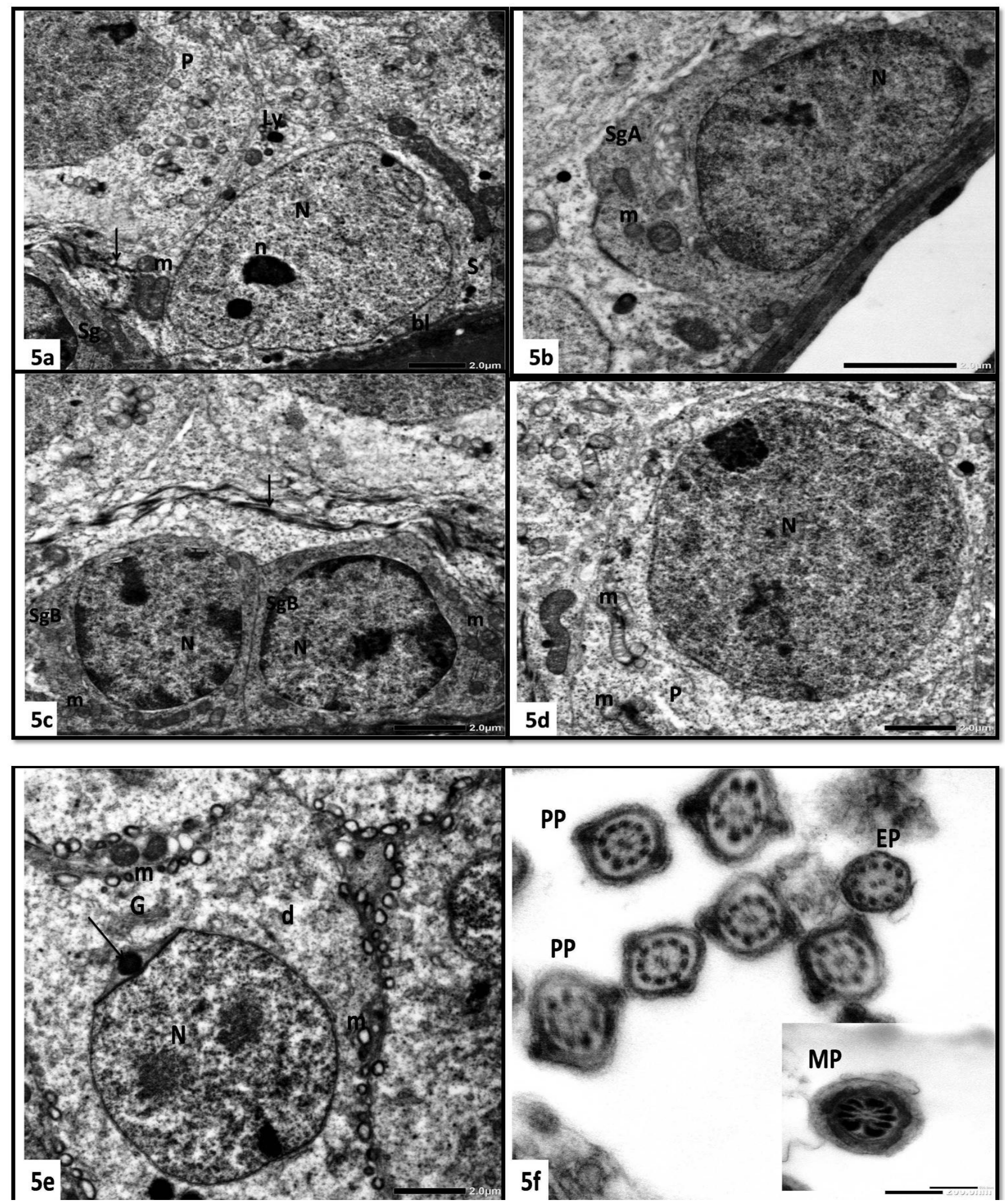

Fig. 5a-f:Electron micrographs of rat seminiferous tubules of group I (control group) showing: (a)-Sertoli cell (S) with large, pale nucleus (N) and prominen nucleolus(n) rests on the basal lamina (bl), the cytoplasm contains mitochondria (m) lysosomes (Ly), Sg; Part of a spermatogonium, P; primary spermatocyte, an intact blood testis barrier( $\uparrow$ ). (b)- Type A spermatogonium ( $\mathrm{SgA}$ ) with an oval nucleus $(\mathrm{N})$ and dark cytoplasm, m; multiple mitochondria. (c)- Two adjacent type B spermatogonia $(\mathrm{SgB})$ with rounded nuclei $(\mathrm{N})$, mitochondria $(\mathrm{m})$, an intact blood testis barrier $(\uparrow)$. (d)- A primary spermatocyte $(\mathrm{P})$ depicts a large rounded nucleus $(\mathrm{N})$ and multiple mitochondria $(\mathrm{m})$. (e)- An early spermatid $(\mathrm{d})$ with pale nucleus $(\mathrm{N})$ and multiple peripherally located mitochondria $(\mathrm{m})$, an acrosomal vesicle $(\uparrow)$, G; Golgi apparatus. (f)-Multiple principle pieces (PP) and an end piece (EP) of sperm tails, the inset shows a middle piece (MP). Uranyl acetate/lead citrate, Mic. Mag. a: x2000, b: x4000, c, d, e: x2500, f: x20000, inset: x25000. 


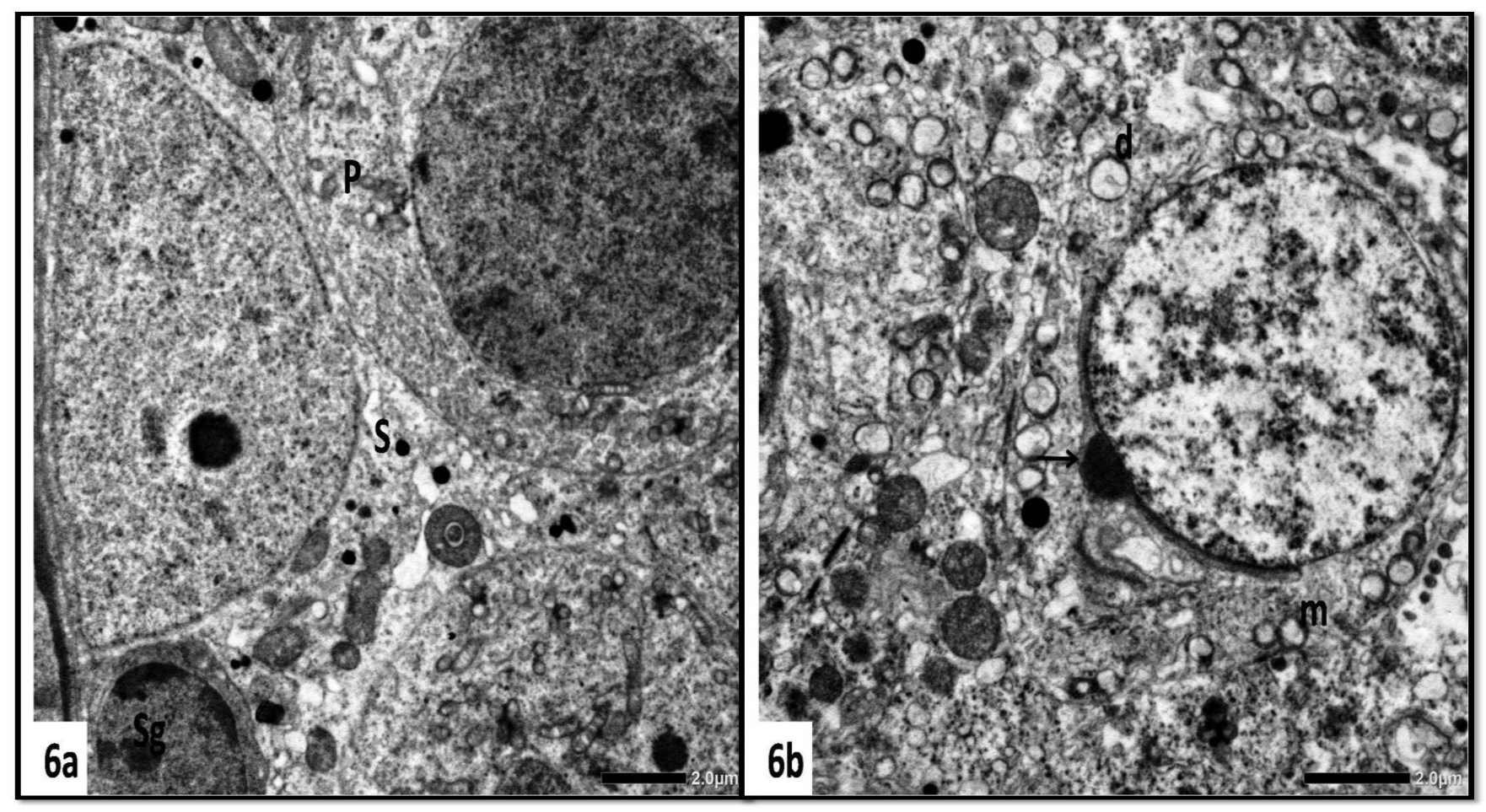

Fig. 6a,b: Electron micrographs of rat seminiferous tubules: group II that received RES showing (a)- A normally appearing Sertoli cell (S), a part of spermatognium (Sg) and primary spermatocyte (P). (b)- An early spermatid (d) with acrosomal vesicle and granule ( $\uparrow$ ) and mitochondria (m). Uranyl acetate lead citrate, Mic. Mag. a: x2000, b: x2500j

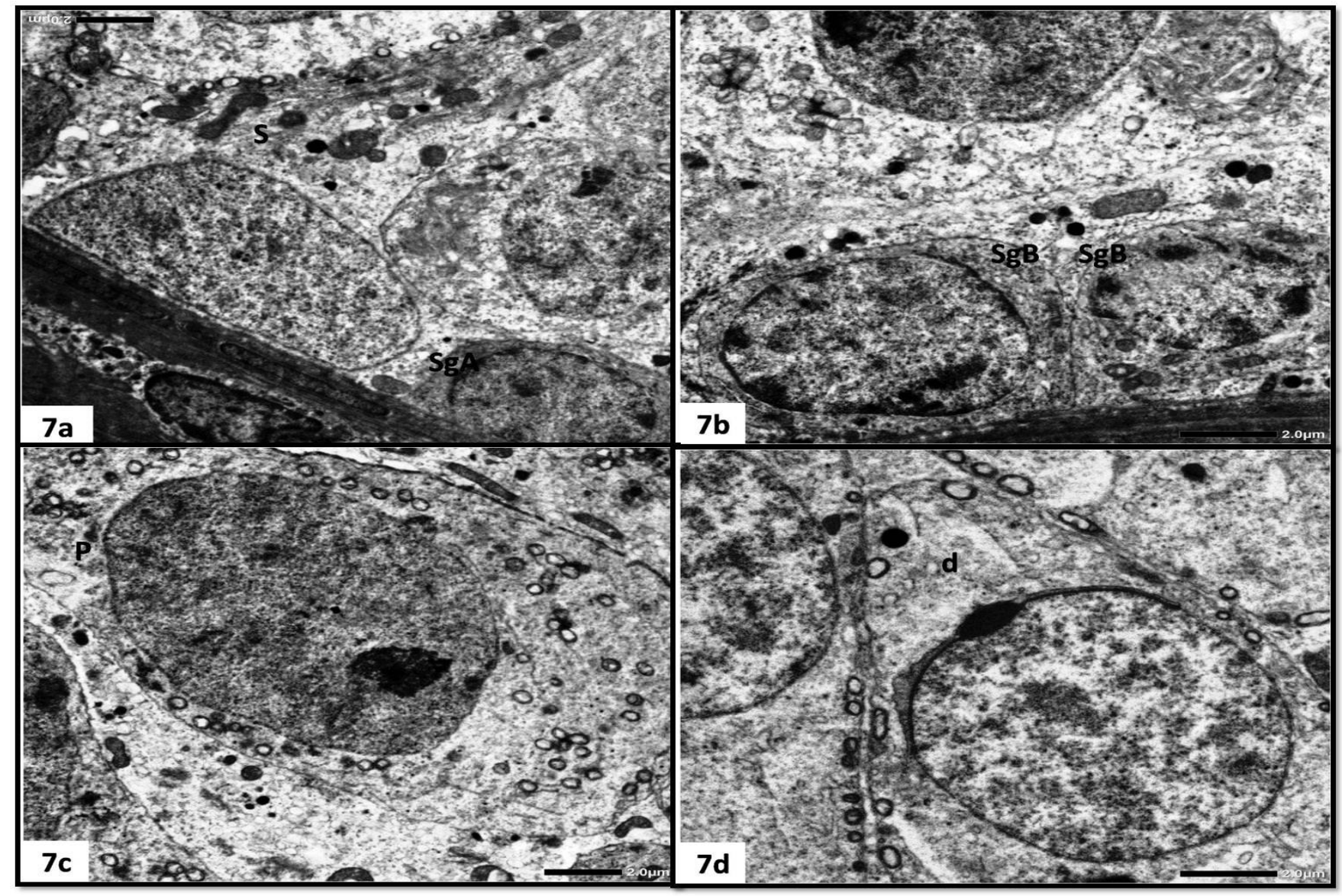

Fig. 7a-d: Electron micrographs of rat seminiferous tubules: group III that received RES-loaded niosomes showing: (a)-normally apparent Sertoli cell (S), type A spermatogonium (SgA). (b)-Two type B spermatogonia(SgB). (c)-Primary spermatocytes(P). (d)- An early permatid (d). Uranyl acetate/lead citrate, Mic. Mag. a: x2000, b: x 2500, c: x2000, d: x2500. 

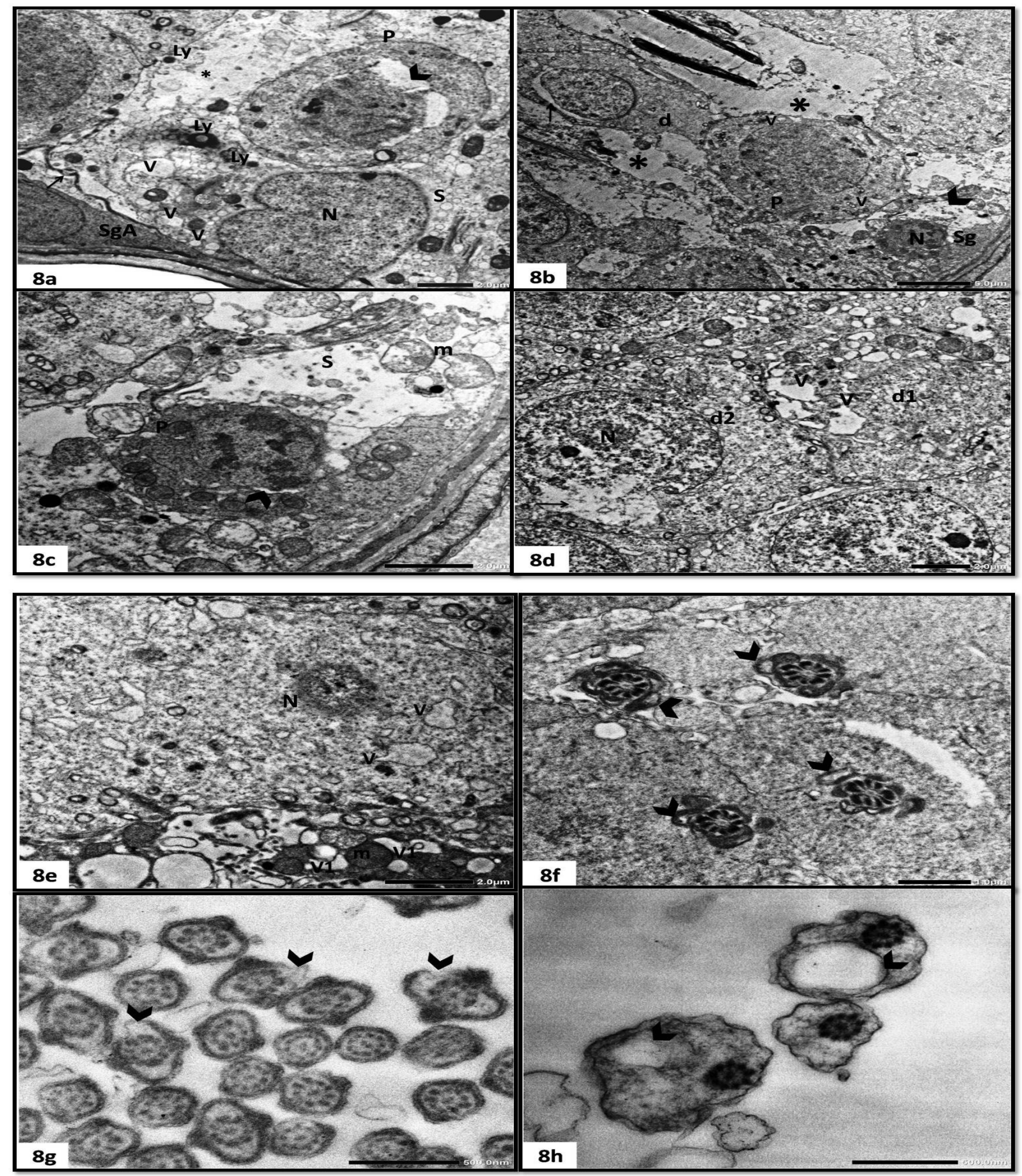

Fig. 8a-h: Electron micrographs of rat testis (group IV) that received TiO2-NPs: (a) Sertoli cell (S) with area of rarified cytoplasm $(*)$, many lysosomes $(\mathrm{Ly})$ and vacuoles $(\mathrm{V})$, primary spermatocyte $(\mathrm{P})$ shows dilated perinuclear cisterna $\left({ }^{\wedge}\right)$, the blood testis barrier exhibits focal dilatation $(\uparrow)$. (b) Disruption of the normal architecture of the seminiferous tubules with large spaces $\left(^{*}\right)$ inbetween the lining cells, a spermatogonium $(\mathrm{Sg})$ with an electron dense nucleus $(\mathrm{N})$ and an area of rarified cytoplasm $(\wedge)$, P; primary spermatocyte with many vacuoles $(\mathrm{V}), \mathrm{d}$; spermatid with dilated perinuclear cistarnae $(\uparrow)$. (c) Primary spermatocyte $(\mathrm{P})$ with dilated perinuclear cisterna $\left({ }^{\wedge}\right)$, an adjacent rarified cytoplasm of Sertoli cell $(\mathrm{S})$ exhibits swollen mitochondria with disrupted cristae (m). (d) Two adjacent early spermatids $(\mathrm{d} 1 \& \mathrm{~d} 2)$, d1 showing cytoplasmic vacuoles $(\mathrm{V})$ of variable sizes and shapes, $\mathrm{d} 2$ shows defective nucleus $(\mathrm{N})$ with focal loss of chromatin ( $\uparrow)$. (e) One of the spermatogenic cells with vacuoles( $(\mathrm{V})$ and small nucleus(N) depicting an abnormal chromatin distribution, an adjacent degenerating Sertoli cell exhibits multiple vacuoles (V1) and swollen mitochondria (m). (f) Middle pieces of sperm tails with swollen disorganized mitochondria and disrupted cristae $\left(^{\wedge}\right)$. (g) Principal pieces with focal interruption of the circumferential ribs $\left({ }^{\wedge}\right)$. (h) End pieces with residual cytoplasm $\left(^{\wedge}\right)$ Uranyl acetate/lead citrate, Mic. Mag. a: x 2000, b: x 1000, c: x 3000, d: x 2000. e: x 3000, f: x 5000, g \& h: x 15000. 

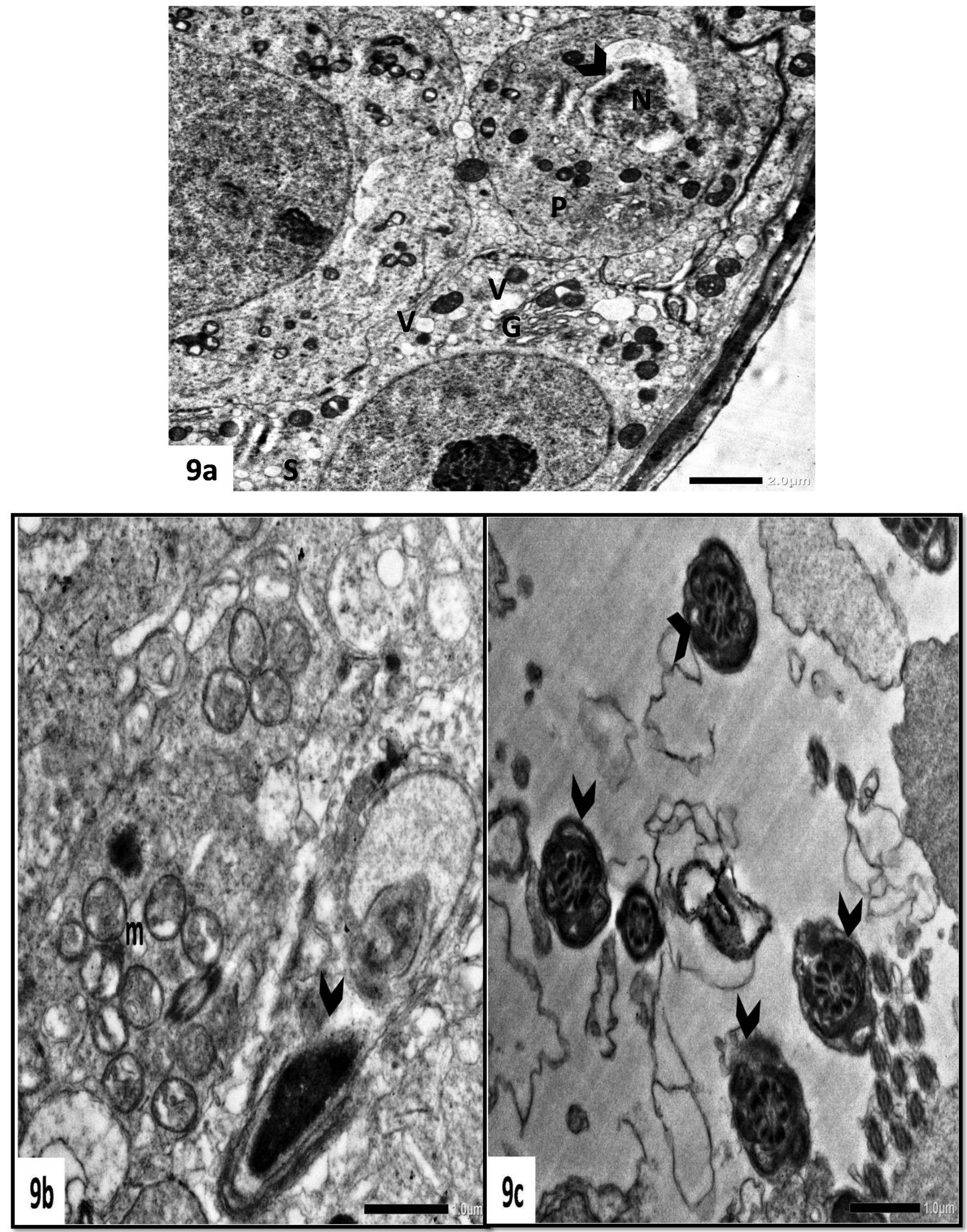

Fig. 9a-c: Electron micrographs of rat testis: Group V that received TiO2-NPs and RES reveal:(a) Sertoli cell (S) with multiple vacuolation (V), a primary spermatocyte $(\mathrm{P})$ with defective nucleus $(\mathrm{N})$ and dilated perinuclear cistarna $\left({ }^{\wedge}\right)$. (b) A defective malformed head of a late spermatid $\left({ }^{\wedge}\right)$, mitochondria with disrupted cristae (m), (c) Middle pieces of sperm tails with swollen and disorganized mitochondria $\left({ }^{\wedge}\right)$. Uranyl acetate/lead citrate, Mic. Mag. a: x 2000, b: x 6000 , c: $x 5000$. 

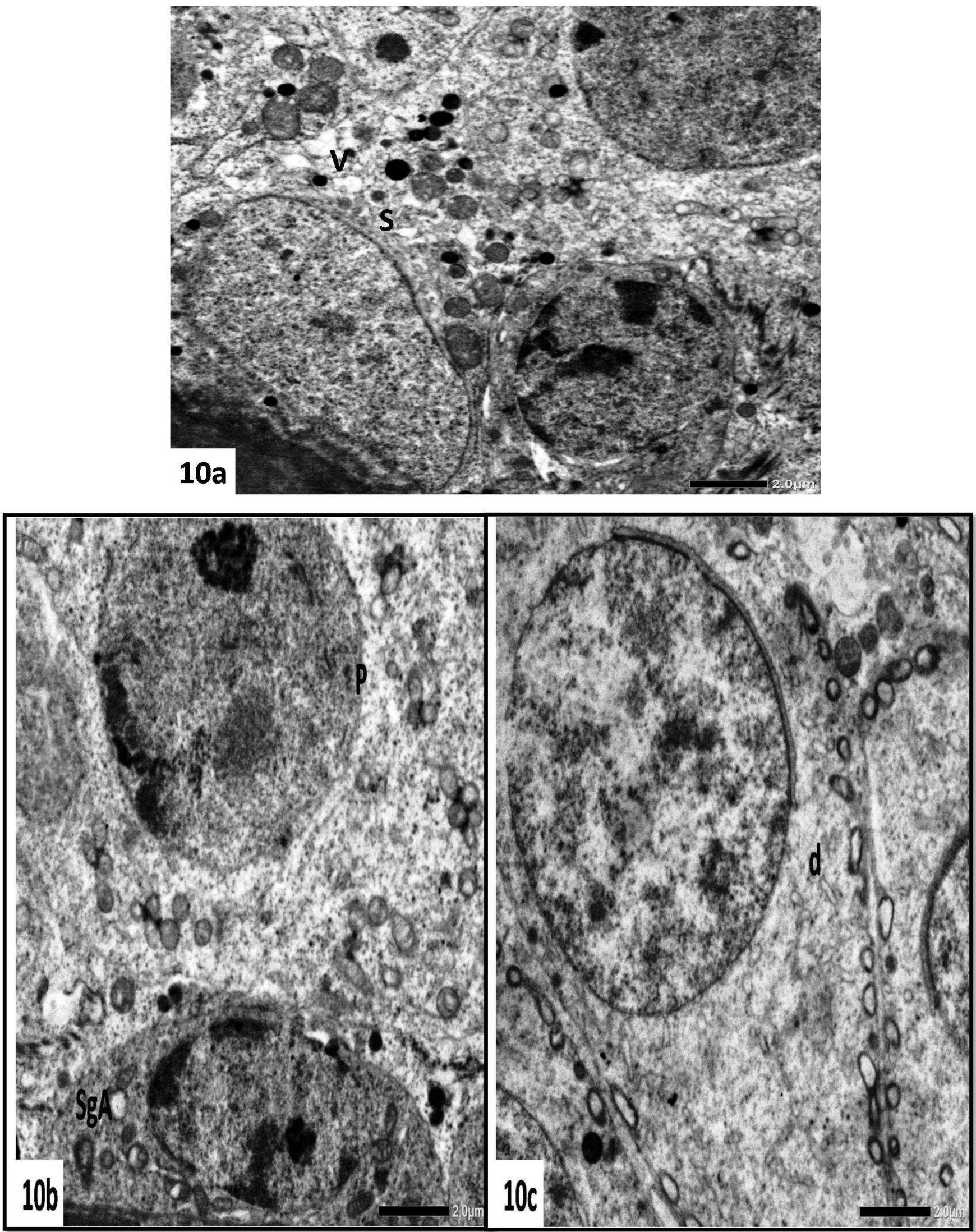

Fig. 10a-c: Electron micrographs of rat testis: group VI that received TiO2-NPs and RES loaded niosomes show apparently normal Sertoli cell as well as spermatogenic cells: (a) Sertoli cell (S) with mild vacuolation (V). (b) Type A spermatogonium (SgA), primary spermatocyte (P). (c) an early permatid (d). Uranyl acetate/lead citrate, Mic. Mag. a: x 2000, b \& c: x 2500 
Table 1: Comparison between the different groups regarding the sperm count, motility, Johnsen score, testosterone, MDA and LDH levels, and testicular weight.

\begin{tabular}{|c|c|c|c|c|c|c|c|}
\hline & Group I & Group II & Group III & Group IV & Group V & Group VI & $P$ \\
\hline Testosterone (ng/mL) & $3.54 \pm 0.51$ & $3.46 \pm 0.52$ & $4.07 \pm 0.54$ & $1.73 \pm 0.45^{\mathrm{abc}}$ & $2.79 \pm 0.49^{\mathrm{abcd}}$ & $3.75 \pm 0.35^{\mathrm{de}}$ & $<0.001^{*}$ \\
\hline $\operatorname{MDA}(\mathrm{nmol} / \mathrm{mL})$ & $5.48 \pm 0.49$ & $5.50 \pm 0.52$ & $5.49 \pm 0.58$ & $8.43 \pm 0.49^{\mathrm{abc}}$ & $6.31 \pm 0.46^{\mathrm{abcd}}$ & $5.53 \pm 0.46^{\mathrm{de}}$ & $<0.001^{*}$ \\
\hline $\mathrm{LDH}(\mathrm{U} / \mathrm{L})$ & $569.50 \pm 28.92$ & $571.10 \pm 33.08$ & $568.30 \pm 41.41$ & $1014.50 \pm 15.09^{\mathrm{abc}}$ & $626.0 \pm 16.54^{\mathrm{abcd}}$ & $570.50 \pm 34.94^{\mathrm{de}}$ & $<0.001^{*}$ \\
\hline Sperm count $\left(\times 10^{6}\right)$ & $80.39 \pm 3.55$ & $80.54 \pm 3.36$ & $84.65 \pm 3.81^{\mathrm{ab}}$ & $68.70 \pm 2.46^{\mathrm{abc}}$ & $70.71 \pm 2.06^{\mathrm{abc}}$ & $84.76 \pm 3.03^{\text {abde }}$ & $<0.001^{*}$ \\
\hline Motile sperm percent & $59.0 \pm 5.81$ & $55.60 \pm 5.39$ & $57.10 \pm 8.55$ & $43.90 \pm 5.48^{\mathrm{abc}}$ & $48.20 \pm 5.47^{\mathrm{abc}}$ & $56.40 \pm 4.97^{\mathrm{de}}$ & $<0.001^{*}$ \\
\hline Johnsen score & $8.80 \pm 0.66$ & $8.40 \pm 0.81$ & $8.60 \pm 0.79$ & $6.30 \pm 1.13^{\mathrm{abc}}$ & $6.70 \pm 0.73^{\mathrm{abc}}$ & $8.30 \pm 0.93^{\mathrm{de}}$ & $<0.001^{*}$ \\
\hline Testicular weight (gm) & $1.29 \pm 0.19$ & $1.28 \pm 0.17$ & $1.30 \pm 0.20$ & $1.24 \pm 0.21$ & $1.25 \pm 0.18$ & $1.32 \pm 0.19$ & 0.939 \\
\hline
\end{tabular}

Data are represented as mean $\pm \mathrm{SD}$.

p: $p$ values for ANOVA test, significance between groups was done using Post Hoc Test (Tukey)

Group I: control group; Group II received RES Group III received RES-loaded niosomes; Group IV received $\mathrm{TiO}_{2}-\mathrm{NPs}_{3}$;roup V received TiO 2 -NPs and

RES; Group VI received $\mathrm{TiO}_{2}$-NPs and RES-loaded niosomes.

HPF: high power field

*: Statistically significant at $p \leq 0.05$

a: significant with group I

b: significant with group II

c: significant with group III

d: significant with group IV

e: significant with group $\mathrm{V}$

\section{DISCUSSION}

In recent years, nanoparticles (NPs) have been widely used in different fields including medicine ${ }^{[1]}$. Owing to their small size, NPs can easily gain access to the blood and lymphatic circulation to reach vital target organs ${ }^{[38]}$, where they can exert deleterious effects on organ functions and overall human health. One of the principal mechanisms by which NPs can produce toxicity is through the formation of reactive oxygen species (ROS). The toxicity potential of NPs is influenced by several variables such as the size, solubility and phase composition of the NP, in addition to its dose, route and the duration of exposure ${ }^{[6,39]}$. However, for any given duration, the toxic effect increases by increasing the dose ${ }^{[8,32,40,41]}$. $\mathrm{TiO}_{2}-\mathrm{NPs}$ are among the most commonly used NPs in various applications.

In the reproductive system, owing to their ability to cross the blood-testis barrier, $\mathrm{TiO}_{2}$-NPs can alter spermatogenesis, which may lead to the reduction of sperm count and motility, increased number of abnormal sperms and increased apoptosis during spermiogenesis ${ }^{[2,32,42]}$. The reproductive hazards of $\mathrm{TiO}_{2} \mathrm{NPs}$ extend to involve down-regulation of the expression of testis-specific genes involved in spermatogenesis or hormone metabolism ${ }^{[43]}$. They are also capable of altering the activities of several testicular enzymes, ultimately resulting in suppression of spermatogenesis ${ }^{[8]}$. The negative effect of $\mathrm{TiO}_{2}$ NPs on spermatogenesis can also be ascribed to their ability to induce apoptosis of Sertoli cells ${ }^{[44]}$. In the present study, pronounced degenerative and vacuolar changes were detected in spermatogenic cells as well as in Sertoli cell. In addition, multinucleated giant cell was encountered inside the tubular lumen containing nuclei of spermatids, the presence of which could be attributed to failure of Sertoli cell to maintain the cytoskeletal bridges closure among cohorts of spermatogenic cells ${ }^{[45]}$. These finding reflect the potential toxic effect of $\mathrm{TiO}_{2}$ NPs on seminiferous epithelium and accordingly on reproduction. This was in accordance with the findings of Sharafutdinova et al., ${ }^{[46]}$ who described degenerative changes in the spermatogenic epithelium including disorganization and detachment of cells following administration of $\mathrm{TiO}_{2} \mathrm{NPs}$.

Accumulation of $\mathrm{TiO}_{2}$ NPs in testicular cells led to decreased antioxidant enzymes, increased production of ROS, lipid peroxidation ${ }^{[25]}$, the release of inflammatory mediators, and protein oxidation. These biochemical changes are suggested to be responsible for DNA damage ${ }^{[6,47]}$, and for the initiation of $\mathrm{TiO}_{2}$ NPs-mediated apoptosis ${ }^{[44,48]}$. Taken together, this might be partly responsible for the detected sperm count and hormonal changes as well as for the degenerative changes in the seminiferous epithelium and sperms following exposure to $\mathrm{TiO}_{2} \mathrm{NPs}$.

Hong et al. ${ }^{[8]}$ found that oral administration of different doses of $\mathrm{TiO}_{2} \mathrm{NPs}$ for 60 days led to histological changes in the testes as well as in the epididymides along with reduction in sperm concentration and motility. In addition, they confirmed that these changes were associated with several biochemical changes including elevated MDA and decreased LDH activities. Morgan et al. ${ }^{[49]}$ also reported that oral administration of $\mathrm{TiO}_{2}$ NPs to male rats for 8 weeks led to significant deterioration in the seminogram, reduction in serum testosterone, increased MDA and decreased glutathione levels. In addition, they detected evident histological alterations in the testicular tissue. Similarly, in accordance with their findings, the administration of $\mathrm{TiO}_{2}$ NPs in the present study led to a significant reduction of the epididymal sperm count and the Johnsen score, which could be attributed to their cytotoxic effect on spermatogenic cells as evidenced by the detected histologic changes in seminiferous tubular epithelium and mature spermatozoa as well. In addition, the light and the electron microscopic changes in the current study were associated with significant 
elevation of LDH and MDA levels, reflecting increased oxidative stress following the administration of $\mathrm{TiO}_{2} \mathrm{NPs}$.

The potential of $\mathrm{TiO}_{2}$ NPs to induce cytotoxicity of Leydig cells ${ }^{[50]}$ contributes to the alteration in serum testosterone level[32]. This was in accordance with the findings in the present study, where a significant decrease in serum testosterone was detected in the group receiving $\mathrm{TiO}_{2}$ NPs. Furthermore, administration of RES-loaded niosomes, but not RES, with $\mathrm{TiO}_{2}$ NPs led to significantly higher serum testosterone level. This decreased testosterone production following the exposure to $\mathrm{TiO}_{2} \mathrm{NPs}$, could be attributed to decreased steroidogenic acute regulatory protein (StAR) gene expression ${ }^{[50]}$, decreased gene expression of CYP17 $\alpha$ and 17ß-hydroxysteroid dehydrogenase and increased expression of cytochrome P450-19 ${ }^{[32,51]}$. Testosterone is crucial not only for spermatogenesis, but also for the function of Sertoli cells, hence any decrease in its level will have a negative impact on spermatogenesis ${ }^{[52]}$.

In the testis, RES was reported to protect against toxicity induced by exposure to several chemicals owing to its anti oxidant and antiapoptotic properties ${ }^{[33-56]}$. Furthermore, its protective role against $\mathrm{TiO}_{2}$ NPs-induced toxicity is believed to be through inhibition of nuclear factor- $\kappa \beta(\mathrm{NF}-\kappa \mathrm{B})^{[17]}$, tumor necrosis factor $\alpha$ (TNF- $\alpha$ ) and interleukin 6 (IL-6) and through phosphorylation of $\mathrm{P} 38$ mitogen activated protein kinase (MAPK) and jun N-terminal kinase (JNK ${ }^{[18]}$.

In cases with chemical-induced testicular toxicity, administering RES was previously reported to reduce MDA levels and to increase gluthathione, catalase and superoxide dismutase. This was associated with an increase in serum testosterone level, sperm count and motility, restoration of altered testicular histology ${ }^{[54-57]}$ and improvement in the Johnsen score, which was dose-dependent ${ }^{[33,56]}$. Furthermore, RES is considered a therapeutic agent for the resultant gonadal dysfunction and infertility ${ }^{[53]}$. Findings of the present study, however, did not reveal a significant increase in sperm count in healthy rats receiving RES compared to controls, which could be attributed to the lower RES dose administered to rats in our study. On the other hand, a significant decrease in $\mathrm{LDH}$ and MDA, and a significant increase in testosterone were detected in the present study following administration of RES with $\mathrm{TiO}_{2}$ NPs compared to when $\mathrm{TiO}_{2}$ NPs were administered alone. The increased testosterone level following RES administration could be attributed to the ability of RES to increase the activity of StAR ${ }^{[58]}$.

RES-loaded nanocarriers were developed to overcome obstacles such as low aqueous solubility, short half-life, high degradability, rapid metabolism, and poor oral bioavailability of RES ${ }^{[20]}$. Higher tissue concentrations of RES were previously detected following administration of RES-loaded nanocarriers compared to the administration of free RES ${ }^{[21]}$. In addition, the antioxidant and anti-inflammatory properties of RES were enhanced by using a RES nanoparticle system $^{[22]}$.
In the current study and in accordance with those findings, administration of RES-loaded niosomes, but not RES, to rats led to significantly higher sperm count, which was even higher than in the control group. Compared to administration of $\mathrm{TiO}_{2} \mathrm{NPs}$ alone, administration of RES-loaded niosomes with $\mathrm{TiO}_{2}$ NPs led to significantly higher serum testosterone and sperm count, and to significantly lower MDA and LDH levels. Furthermore, administration of RES with $\mathrm{TiO}_{2} \mathrm{NPs}$ was neither associated with significant improvement in the Johnsen score nor with improvement of histologic changes, which could be explained by the low aqueous solubility of the compound. Nevertheless, a significant increase in the Johnsen score was observed on administration of RES-loaded niosomes with $\mathrm{TiO}_{2} \mathrm{NPs}$ compared to the group receiving $\mathrm{TiO}_{2} \mathrm{NPs}$ alone or the group receiving RES with $\mathrm{TiO}_{2} \mathrm{NPs}$; this was associated with apparent structural improvement that was detected on light and electron microscopic examination.

\section{CONCLUSION}

$\mathrm{TiO}_{2}$ NPs exerts a negative impact on testicular structure and function and accordingly on reproduction. RES incorporated in a nanocarrier, but not free RES, was able to exert a protective effect against $\mathrm{TiO}_{2} \mathrm{NPs}$ - induced testicular damage; this was evident by the significant increase of sperm count, serum testosterone and Johnsen score, and the significant reduction of the markers of oxidative stress and the structural improvement seen on light and electron microscopic examination, which could be attributed to the improved physicochemical properties of RES in RES-loaded niosomes. To the best of our knowledge, this is the first study to evaluate the effect of RES-loaded niosomes on $\mathrm{TiO}_{2} \mathrm{NPs}$ induced testicular toxicity.

\section{CONFLICTS OF INTEREST}

There are no conflicts of interest.

\section{REFERENCES}

1. Zhang L, Gu FX, Chan JM, Wang AZ, Langer RS, Farokhzad OC. Nanoparticles in medicine: therapeutic applications and developments. Clin Pharmacol Ther. 2008 May;83(5):761-9.

2. Fadeel B, Garcia-Bennett AE. Better safe than sorry: Understanding the toxicological properties of inorganic nanoparticles manufactured for biomedical applications. Adv Drug Deliv Rev. 2010 Mar 8;62(3):362-74.

3. Rollerova E, Tulinska J, Liskova A, Kuricova M, Kovriznych J, Mlynarcikova A, et al. Titanium dioxide nanoparticles: some aspects of toxicity/focus on the development. Endocr Regul. 2015 Apr;49(2):97-112.

4. Jia X, Wang S, Zhou L, Sun L. The Potential Liver, Brain, and Embryo Toxicity of Titanium Dioxide Nanoparticles on Mice. Nanoscale Res Lett. 2017 Dec;12(1):478. 
5. Zhang X, Li W, Yang Z. Toxicology of nanosized titanium dioxide: an update. Arch Toxicol. 2015 Dec;89(12):2207-17.

6. Brohi RD, Wang L, Talpur HS, Wu D, Khan FA, Bhattarai D, et al. Toxicity of Nanoparticles on the Reproductive System in Animal Models: A Review. Front Pharmacol. 2017;8:606.

7. Klien K, Godnic-Cvar J. Genotoxicity of metal nanoparticles: focus on in vivo studies. Arh Hig Rada Toksikol. 2012 Jun 1;63(2):133-45.

8. Hong F, Si W, Zhao X, Wang L, Zhou Y, Chen $\mathrm{M}$, et al. TiO2 Nanoparticle Exposure Decreases Spermatogenesis via Biochemical Dysfunctions in the Testis of Male Mice. J Agric Food Chem. 2015 Aug 12;63(31):7084-92.

9. Zhao X, Ze Y, Gao G, Sang X, Li B, Gui S, et al. Nanosized TiO2-induced reproductive system dysfunction and its mechanism in female mice. PLoS One. 2013;8(4):e59378.

10. Guo LL, Liu XH, Qin DX, Gao L, Zhang HM, Liu JY, et al. [Effects of nanosized titanium dioxide on the reproductive system of male mice]. Zhonghua $\mathrm{Nan} \mathrm{Ke}$ Xue. 2009 Jun;15(6):517-22.

11. Miura N, Ohtani K, Hasegawa T, Yoshioka H, Hwang GW. High sensitivity of testicular function to titanium nanoparticles. J Toxicol Sci. 2017;42(3):359-66.

12. Takeda K, Suzuki K, Ishihara A, Kubo-Irie M, Fujimoto $\mathrm{R}$, Tabata $\mathrm{M}$, et al. Nanoparticles transferred from pregnant mice to their offspring can damage the genital and cranial nerve systems. J Health. 2009;55:95-102.

13. Pirola L, Frojdo S. Resveratrol: one molecule, many targets. IUBMB Life. 2008 May;60(5):323-32.

14. Koushki M, Amiri-Dashatan N, Ahmadi N, Abbaszadeh HA, Rezaei-Tavirani M. Resveratrol: A miraculous natural compound for diseases treatment. Food Sci Nutr. 2018 Nov;6(8):2473-90.

15. Jiang YG, Peng T, Luo Y, Li MC, Lin YH. Resveratrol reestablishes spermatogenesis after testicular injury in rats caused by 2, 5-hexanedione. Chin Med J (Engl). 2008 Jul 5;121(13):1204-9.

16. Weiskirchen S, Weiskirchen R. Resveratrol: How Much Wine Do You Have to Drink to Stay Healthy? Adv Nutr. 2016 Jul;7(4):706-18.

17. Luo G, Li Z, Wang Y, Wang H, Zhang Z, Chen W, et al. Resveratrol Protects against Titanium Particle-Induced Aseptic Loosening Through Reduction of Oxidative Stress and Inactivation of NF-kappaB. Inflammation. 2016 Apr;39(2):775-85.

18. $\mathrm{Hu} \mathrm{H}$, Li L, Guo Q, Jin S, Zhou Y, Oh Y, et al. A mechanistic study to increase understanding of titanium dioxide nanoparticles-increased plasma glucose in mice. Food Chem Toxicol. 2016 Sep;95:175-87.
19. Baur JA, Sinclair DA. Therapeutic potential of resveratrol: the in vivo evidence. Nat Rev Drug Discov. 2006 Jun;5(6):493-506.

20. Penalva R, Morales J, Gonzalez-Navarro CJ, Larraneta E, Quincoces G, Penuelas I, et al. Increased Oral Bioavailability of Resveratrol by Its Encapsulation in Casein Nanoparticles. Int J Mol Sci. 2018 Sep 18;19(9):E2816.

21. Frozza RL, Bernardi A, Paese K, Hoppe JB, da Silva $\mathrm{T}$, Battastini AM, et al. Characterization of transresveratrol-loaded lipid-core nanocapsules and tissue distribution studies in rats. J Biomed Nanotechnol. 2010 Dec;6(6):694-703.

22. Lee CW, Yen FL, Huang HW, Wu TH, Ko HH, Tzeng WS, et al. Resveratrol nanoparticle system improves dissolution properties and enhances the hepatoprotective effect of resveratrol through antioxidant and anti-inflammatory pathways. J Agric Food Chem. 2012 May 9;60(18):4662-71.

23. Rajera R, Nagpal K, Singh SK, Mishra DN. Niosomes: a controlled and novel drug delivery system. Biol Pharm Bull. 2011;34(7):945-53.

24. Moghassemi S, Hadjizadeh A. Nano-niosomes as nanoscale drug delivery systems: an illustrated review. J Control Release. 2014 Jul 10;185:22-36.

25. Meena R, Kajal K, R P. Cytotoxic and genotoxic effects of titanium dioxide nanoparticles in testicular cells of male wistar rat. Appl Biochem Biotechnol. 2015 Jan;175(2):825-40.

26. Das S, Lin HS, Ho PC, Ng KY. The impact of aqueous solubility and dose on the pharmacokinetic profiles of resveratrol. Pharm Res. 2008 Nov;25(11):2593-600.

27. Pando D, Gutierrez G, Coca J, Pazos C. Preparation and characterization of niosomes containing resveratrol. J Food Eng. 2013;117:227-34.

28. Ruckmani K, Sankar V. Formulation and optimization of Zidovudine niosomes. AAPS PharmSciTech. 2010 Sep;11(3):1119-27.

29. Pujara N, Jambhrunkar S, Wong KY, McGuckin M, Popat A. Enhanced colloidal stability, solubility and rapid dissolution of resveratrol by nanocomplexation with soy protein isolate. J Colloid Interface Sci. 2017 Feb 15;488:303-8.

30. Singh SK, Makadia V, Sharma S, Rashid M, Shahi $\mathrm{S}$, Mishra PR, et al. Preparation and in-vitro/in-vivo characterization of trans-resveratrol nanocrystals for oral administration. Drug Deliv Transl Res. 2017 Jun;7(3):395-407.

31. Cenesiz S, Yarim GF, Karabulut AB, Ara C. Changing of antioxidant enzyme activity on the biliary obstructed rats treated with resveratrol. Dtsch Tierarztl Wochenschr. 2007 Sep;114(9):345-8. 
32. Gao G, Ze Y, Zhao X, Sang X, Zheng L, Ze X, et al. Titanium dioxide nanoparticle-induced testicular damage, spermatogenesis suppression, and gene expression alterations in male mice. J Hazard Mater. 2013 Aug 15;258-259:133-43.

33. Satoh K. Serum lipid peroxide in cerebrovascular disorders determined by a new colorimetric method. Clin Chim Acta. 1978 Nov 15;90(1):37-43.

34. Jovanovic P, Zoric L, Stefanovic I, Dzunic B, DjordjevicJocic J, Radenkovic M, et al. Lactate dehydrogenase and oxidative stress activity in primary open-angle glaucoma aqueous humour. Bosn J Basic Med Sci. $2010 \mathrm{Feb} ; 10(1): 83-8$.

35. Lewis-Jones DI, Kerrigan DD. A modified Johnsen's count for evaluation of spermatogenesis in the rat. IRCS Med Sci. 1985;13(6):510-11.

36. Carleton HM, Drury RAB, A. WE. Carleton's Histological Technique. 5th ed. Oxford, New York, Toronto.: Oxford University Press; 1980.

37. Vega SG, Guzman P, Garcia L, Espinosa J, Cortinas de Nava C. Sperm shape abnormality and urine mutagenicity in mice treated with niclosamide. Mutat Res. 1988 Feb;204(2):269-76.

38. Oberdorster G, Oberdorster E, Oberdorster J. Nanotoxicology: an emerging discipline evolving from studies of ultrafine particles. Environ Health Perspect. 2005 Jul;113(7):823-39.

39. Sayes CM, Wahi R, Kurian PA, Liu Y, West JL, Ausman $\mathrm{KD}$, et al. Correlating nanoscale titania structure with toxicity: a cytotoxicity and inflammatory response study with human dermal fibroblasts and human lung epithelial cells. Toxicol Sci. 2006 Jul;92(1):174-85.

40. Wang J, Zhou G, Chen $\mathrm{C}$, Yu H, Wang $\mathrm{T}$, Ma $\mathrm{Y}$, et al. Acute toxicity and biodistribution of different sized titanium dioxide particles in mice after oral administration. Toxicol Lett. 2007 Jan 30;168(2):176-85.

41. Gao G, Ze Y, Li B, Zhao X, Zhang T, Sheng L, et al. Ovarian dysfunction and gene-expressed characteristics of female mice caused by long-term exposure to titanium dioxide nanoparticles. J Hazard Mater. 2012 Dec;243:19-27.

42. Miura N, Ohtani K, Hasegawa T, Hojo R, Yanagiba y, Suzuki T, et al. Hazardous effects of titanium dioxide nanoparticles on testicular function in mice. Fund Toxicol Sci. 2014;1(3):81-5.

43. Hong F, Zhao X, Si W, Ze Y, Wang L, Zhou Y, et al. Decreased spermatogenesis led to alterations of testisspecific gene expression in male mice following nano-TiO2 exposure. J Hazard Mater. 2015 Dec 30;300:718-28.
44. Hong F, Zhao X, Chen M, Zhou Y, Ze Y, Wang L, et al. $\mathrm{TiO}_{2}$ nanoparticles-induced apoptosis of primary cultured Sertoli cells of mice. J Biomed Mater Res A. 2015 Jan;104(1):124-35.

45. Greaves P. Male genital tract. Histopathology of Preclinical Toxicity Studies: Interpretation and Relevance in Drug Safety Evaluation. $4^{\text {th }}$ ed. Amsterdam: Elsevier; 2012. p. 615-66.

46. Sharafutdinova LA, Fedorova AM, Bashkatov SA, Sinel'nikov KN, Valiullin VV. Structural and Functional Analysis of the Spermatogenic Epithelium in Rats Exposed to Titanium Dioxide Nanoparticles. Bull Exp Biol Med. 2018 Dec;166(2):279-82.

47. Hirakawa K, Mori M, Yoshida M, Oikawa S, Kawanishi S. Photo-irradiated titanium dioxide catalyzes site specific DNA damage via generation of hydrogen peroxide. Free Radic Res. 2004 May;38(5):439-47.

48. Chen T, Yan J, Li Y. Genotoxicity of titanium dioxide nanoparticles. J Food Drug Anal. 2014 Mar; 22(1):95-104.

49. Morgan AM, Ibrahim MA, Noshy PA. Reproductive toxicity provoked by titanium dioxide nanoparticles and the ameliorative role of Tiron in adult male rats. Biochem Biophys Res Commun. 2017 Apr 29;486(2):595-600.

50. Komatsu T, Tabata M, Kubo-Irie M, Shimizu T, Suzuki K, Nihei Y, et al. The effects of nanoparticles on mouse testis Leydig cells in vitro. Toxicol In Vitro. 2008 Dec;22(8):1825-31.

51. Jia F, Sun Z, Yan X, Zhou B, Wang J. Effect of pubertal nano-TiO2 exposure on testosterone synthesis and spermatogenesis in mice. Arch Toxicol. 2014 Mar;88(3):781-8.

52. Smith LB, Walker WH. The regulation of spermatogenesis by androgens. Semin Cell Dev Biol. 2014 Jun;30:2-13.

53. Ozatik FY, Ozatik O, Yigitaslan S, Unel CC, Erol K. Protective role of resveratrol on testicular germ cells in mice with testicular toxicity. Turk $\mathrm{J}$ Urol. 2017 Dec;43(4):444-50.

54. Singh I, Goyal Y, Ranawat P. Potential chemoprotective role of resveratrol against cisplatin induced testicular damage in mice. Chem Biol Interact. 2017 Aug 1;273:200-11.

55. Banerjee B, Nandi P, Chakraborty S, Raha S, Sen PC, Jana K. Resveratrol ameliorates benzo(a)pyrene-induced testicular dysfunction and apoptosis: involvement of p38 MAPK/ATF2/iNOS signaling. J Nutr Biochem. 2016 Aug;34:17-29.

56. Yulug E, Turedi S, Alver A, Kahraman C. Effects of resveratrol on methotrexate-induced testicular damage in rats. ScientificWorldJournal. 2013;2013:489659. 
57. Juan ME, Gonzalez-Pons E, Munuera T, Ballester J, Rodriguez-Gil JE, Planas JM. trans-Resveratrol, a natural antioxidant from grapes, increases sperm output in healthy rats. J Nutr. 2005 Apr;135(4):757-60.

58. Banerjee B, Chakraborty S, Chakraborty P, Ghosh D,
Jana K. Protective Effect of Resveratrol on Benzo(a) Pyrene Induced Dysfunctions of Steroidogenesis and Steroidogenic Acute Regulatory Gene Expression in Leydig Cells. Front Endocrinol (Lausanne). 2019;10:272. 


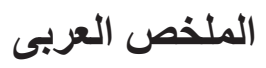

\section{دراسة نسيجية لمقارنة التأثير الوقائى المحتمل للريسفيراترول مقابل الريسفيراترول المحمل على الاجسام المتناهية الصغر ضد السمية الناجمة عن جزئيات ثناني أكسيد

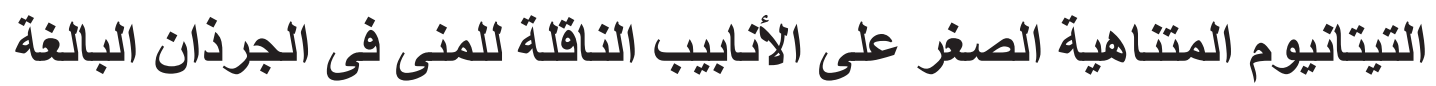

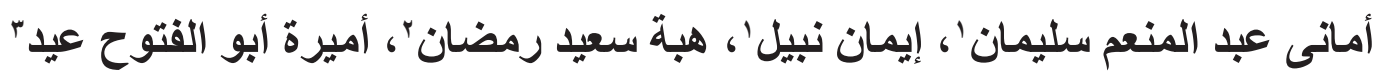

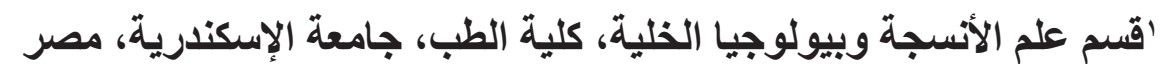

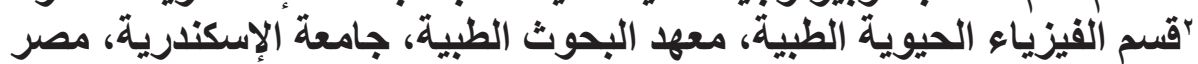

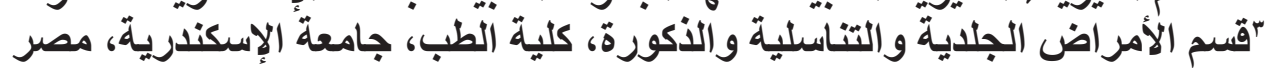

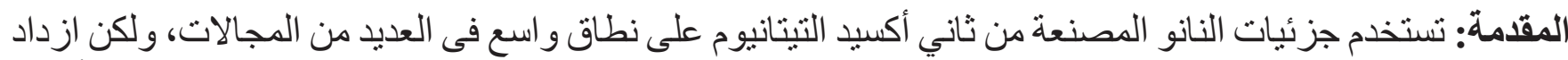

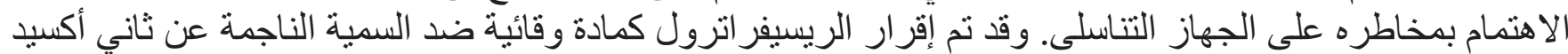
التيتانيو و ذللك من خلال خصائصده كعامل ضد التد الأكسدة و الالتهابات.

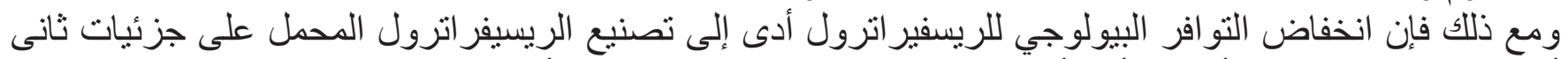

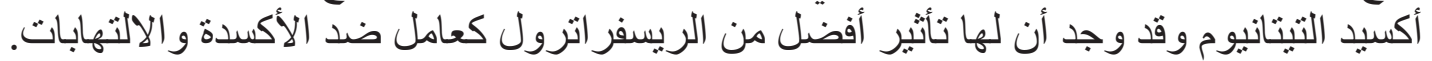

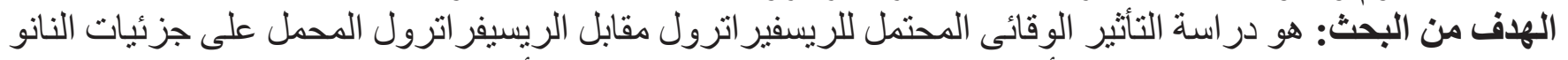

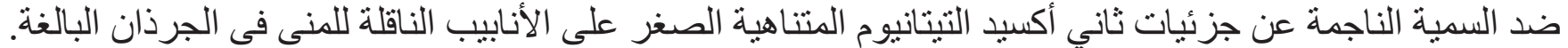

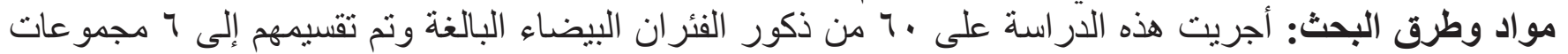
متساوية: مواد وطري

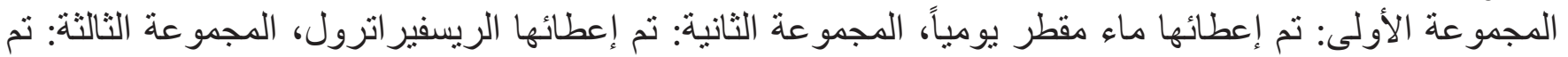

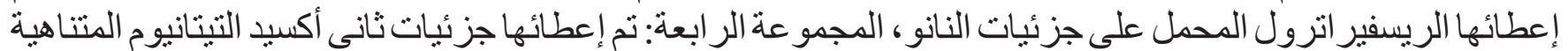

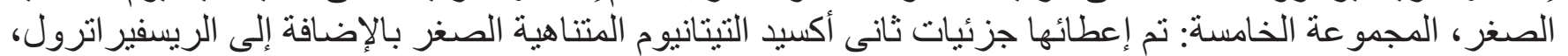

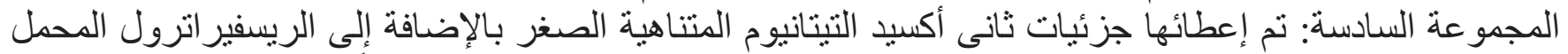

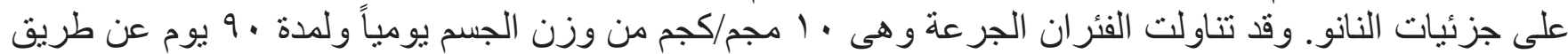
أنبوبة المعدة. وفى نهاية التجربة تم ذبح الفئر ان، وسحب عينة من الدم لقياس مستوى هرمون التيستو ستيرون وقياس عو امل الأكسدة،

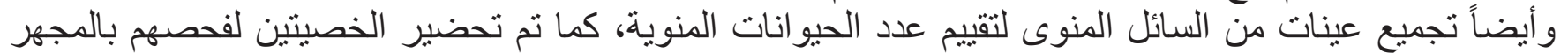

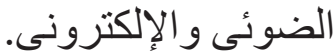
النتائج: أظهرت الإكر استة أن إعطاء جزئيات ثاني أكسيد التيتانيوم المتناهية الصغر أدى إلى انخفاض ملحوظ في مستوى

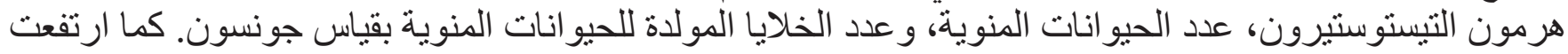

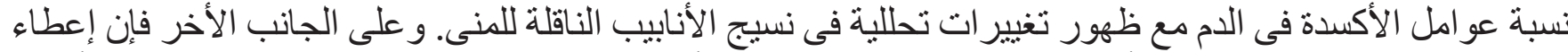

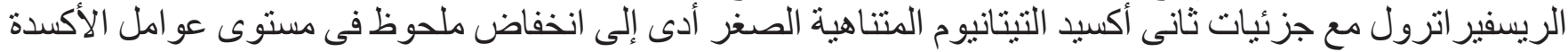

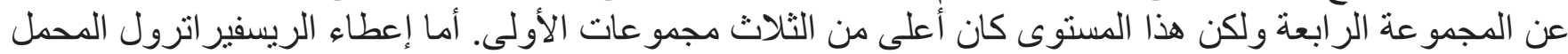

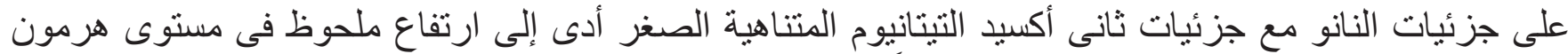

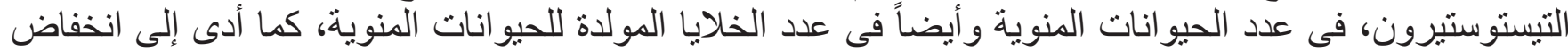

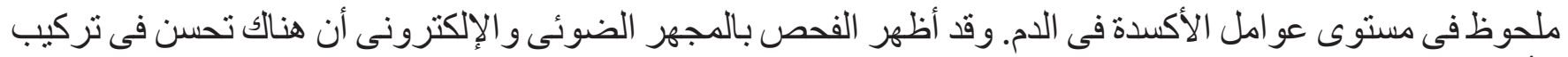

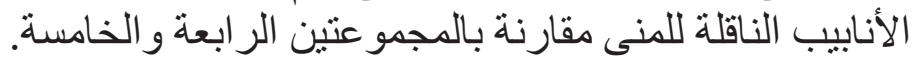

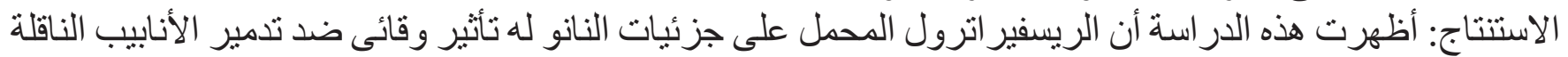

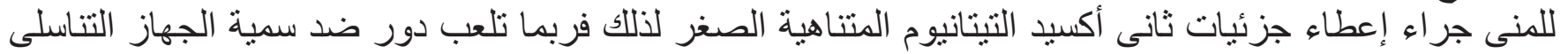
الناجمة من جزئيات النانو. 